\title{
LEVEL II SCOUR ANALYSIS FOR BRIDGE 17 (BURKTH00070017) on TOWN HIGHWAY 7, crossing DISH MILL BROOK, BURKE, VERMONT
}

Open-File Report 97-757

Prepared in cooperation with

VERMONT AGENCY OF TRANSPORTATION

and

FEDERAL HIGHWAY ADMINISTRATION

U.S. Department of the Interior

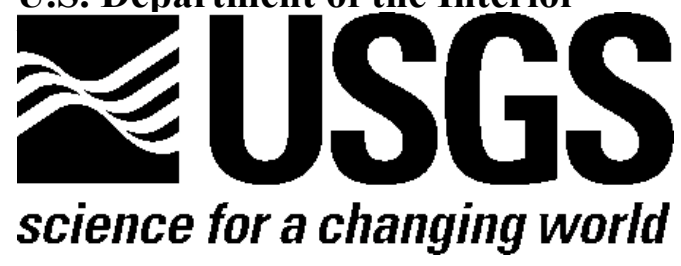




\section{LEVEL II SCOUR ANALYSIS FOR BRIDGE 17 (BURKTH00070017) on TOWN HIGHWAY 7, crossing DISH MILL BROOK, BURKE, VERMONT}

By RONDA L. BURNS and ERICK M. BOEHMLER

U.S. Geological Survey Open-File Report 97-757

Prepared in cooperation with

VERMONT AGENCY OF TRANSPORTATION

and

FEDERAL HIGHWAY ADMINISTRATION 


\title{
U.S. DEPARTMENT OF THE INTERIOR BRUCE BABBITT, Secretary
}

\author{
U.S. GEOLOGICAL SURVEY \\ Mark Schaefer, Acting Director
}

For additional information write to:

District Chief

U.S. Geological Survey 361 Commerce Way

Pembroke, NH 03275-3718
Copies of this report may be purchased from:

U.S. Geological Survey

Branch of Information Services

Open-File Reports Unit

Box 25286

Denver, CO 80225-0286 


\section{CONTENTS}

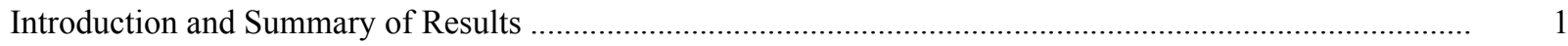

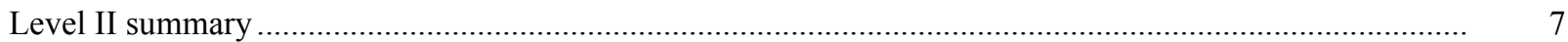

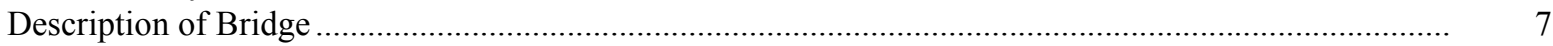

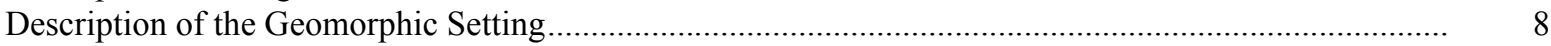

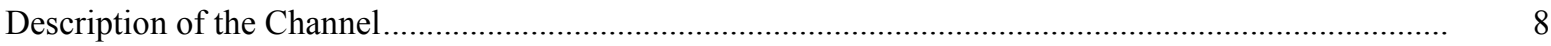

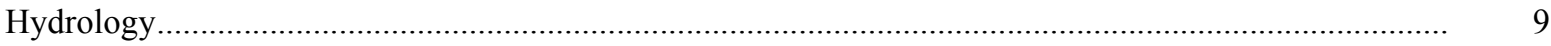

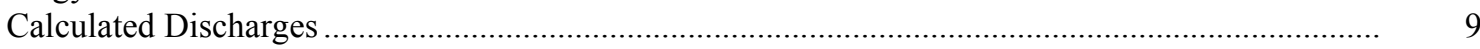

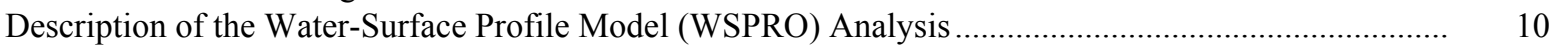

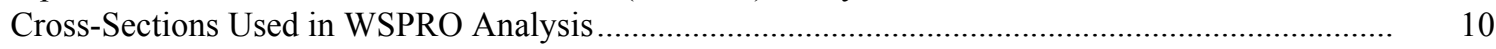

Data and Assumptions Used in WSPRO Model ...................................................................... 11

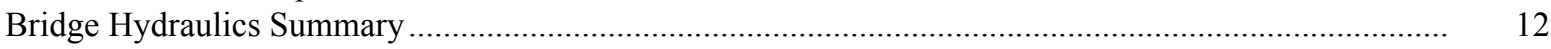

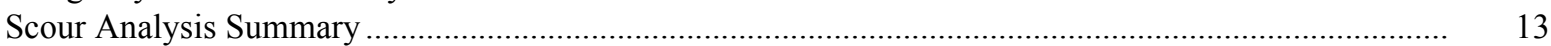

Special Conditions or Assumptions Made in Scour Analysis ...................................................... 13

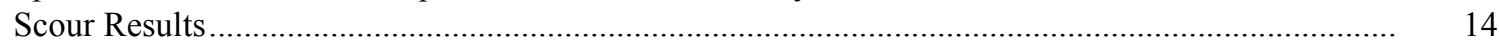

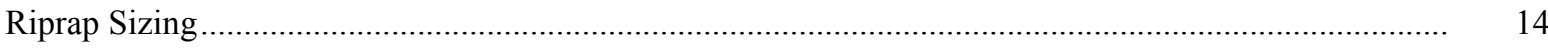

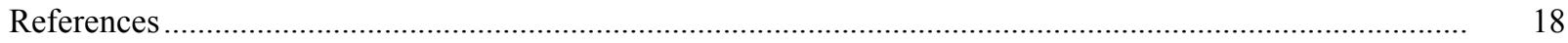

Appendixes:

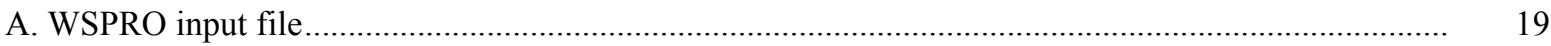

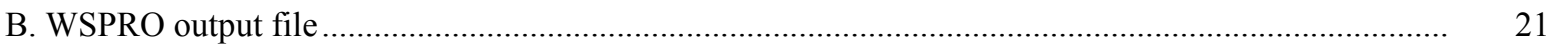

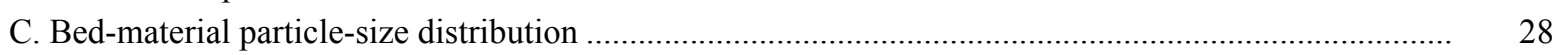

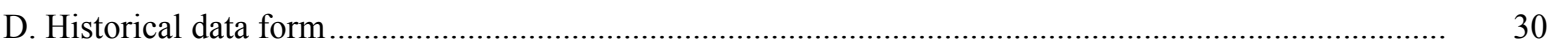

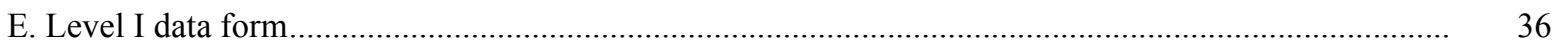

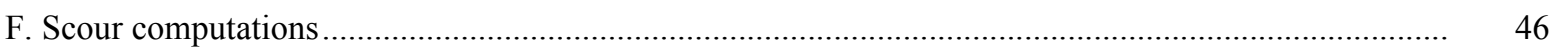

\section{FIGURES}

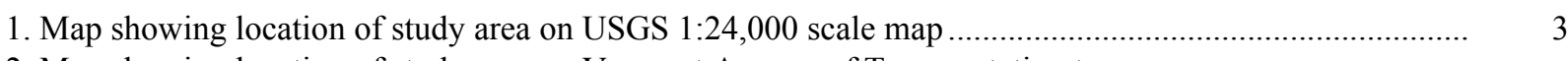

2. Map showing location of study area on Vermont Agency of Transportation town
highway map

3. Structure BURKTH00070017 viewed from upstream (August 7, 1995) ................................................ 5

4. Downstream channel viewed from structure BURKTH00070017 (August 7, 1995) ............................ 5

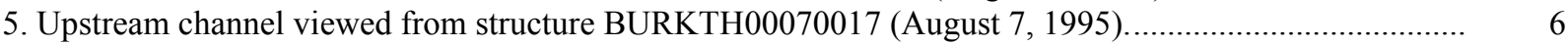

6. Structure BURKTH00070017 viewed from downstream (August 7, 1995)........................................ 6

7. Water-surface profiles for the 100- and 500-year discharges at structure BURKTH00070017 on Town Highway 7, crossing Dish Mill Brook,

Burke, Vermont.

8. Scour elevations for the 100- and 500-year discharges at structure

BURKTH00070017 on Town Highway 7, crossing Dish Mill Brook,

Burke, Vermont.

(1)

5

5

(1)

(1)

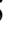

\section{TABLES}

1. Remaining footing/pile depth at abutments for the 100-year discharge at structure

BURKTH00070017 on Town Highway 7, crossing Dish Mill Brook,

Burke, Vermont

2. Remaining footing/pile depth at abutments for the 500-year discharge at structure

BURKTH00070017 on Town Highway 7, crossing Dish Mill Brook,

Burke, Vermont... 


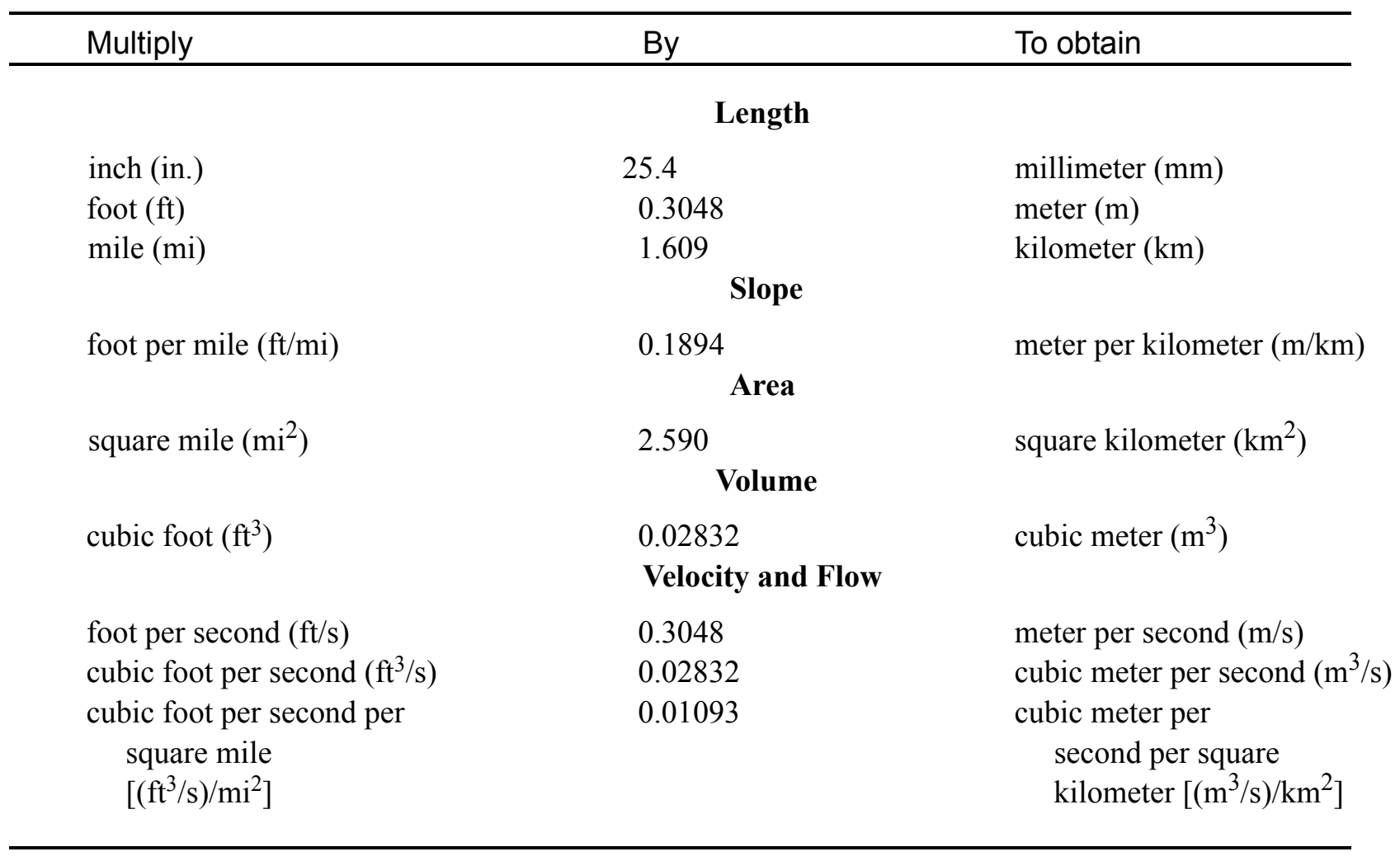

\section{OTHER ABBREVIATIONS}

$\begin{array}{lrlr}\mathrm{BF} & \text { bank full } & \text { LWW } & \text { left wingwall } \\ \mathrm{cfs} & \text { cubic feet per second } & \text { MC } & \text { main channel } \\ \mathrm{D}_{50} & \text { median diameter of bed material } & \text { RAB } & \text { right abutment } \\ \mathrm{DS} & \text { downstream } & \text { RABUT } & \text { face of right abutment } \\ \mathrm{elev} & \text { elevation } & \text { RB } & \text { right bank } \\ \mathrm{f} / \mathrm{p} & \text { flood plain } & \text { ROB } & \text { right overbank } \\ \mathrm{ft}^{2} & \text { square feet } & \text { RWW } & \text { right wingwall } \\ \mathrm{ft} / \mathrm{ft} & \text { feet per foot } & \text { TH } & \text { town highway } \\ \mathrm{JCT} & \text { junction } & \text { UB } & \text { under bridge } \\ \mathrm{LAB} & \text { left abutment } & \text { US } & \text { upstream } \\ \mathrm{LABUT} & \text { face of left abutment } & \text { USGS } & \text { United States Geological Survey } \\ \mathrm{LB} & \text { left bank } & \text { VTAOT Vermont Agency of Transportation } \\ \mathrm{LOB} & \text { left overbank } & \text { WSPRO } & \text { water-surface profile model }\end{array}$

In this report, the words "right" and "left" refer to directions that would be reported by an observer facing downstream. Sea level: In this report, "sea level" refers to the National Geodetic Vertical Datum of 1929-- a geodetic datum derived from a general adjustment of the first-order level nets of the United States and Canada, formerly called Sea Level Datum of 1929.

In the appendices, the above abbreviations may be combined. For example, USLB would represent upstream left bank. 


\title{
LEVEL II SCOUR ANALYSIS FOR BRIDGE 17 (BURKTH00070017) ON TOWN HIGHWAY 7, CROSSING DISH MILL BROOK, BURKE, VERMONT
}

\author{
By Ronda L. Burns and Erick M. Boehmler
}

\section{INTRODUCTION AND SUMMARY OF RESULTS}

This report provides the results of a detailed Level II analysis of scour potential at structure BURKTH00070017 on Town Highway 7 crossing Dish Mill Brook, Burke, Vermont (figures 1-8). A Level II study is a basic engineering analysis of the site, including a quantitative analysis of stream stability and scour (U.S. Department of Transportation, 1993). Results of a Level I scour investigation also are included in Appendix E of this report. A Level I investigation provides a qualitative geomorphic characterization of the study site. Information on the bridge, gleaned from Vermont Agency of Transportation (VTAOT) files, was compiled prior to conducting Level I and Level II analyses and is found in Appendix D.

The site is in the White Mountain section of the New England physiographic province in northeastern Vermont. The 5.9- $\mathrm{mi}^{2}$ drainage area is in a predominantly rural and forested basin. In the vicinity of the study site, the surface cover is forest on the upstream banks and the downstream right bank. On the downstream left bank, the surface cover is shrub and brushland while the immediate bank is forested.

In the study area, Dish Mill Brook has an incised, sinuous channel with a slope of approximately $0.04 \mathrm{ft} / \mathrm{ft}$, an average channel top width of $39 \mathrm{ft}$ and an average bank height of $3 \mathrm{ft}$. The channel bed material ranges from gravel to boulder with a median grain size $\left(\mathrm{D}_{50}\right)$ of $79.2 \mathrm{~mm}(0.241 \mathrm{ft})$. The geomorphic assessment at the time of the Level I and Level II site visit on August 7, 1995, indicated that the reach was unstable. Moderate fluvial erosion has resulted in cut-banks on the upstream and downstream channel banks.

The Town Highway 7 crossing of Dish Mill Brook is a 26-ft-long, two-lane bridge consisting of one 23-foot steel-beam span (Vermont Agency of Transportation, written communication, March 3, 1995). The opening length of the structure parallel to the bridge face is $22.5 \mathrm{ft}$. The bridge is supported by vertical, concrete abutments with wingwalls. The channel is skewed approximately 10 degrees to the opening while the opening-skew-toroadway is zero degrees. 
A scour hole $1.5 \mathrm{ft}$ deeper than the mean thalweg depth was observed along the downstream end of the left abutment and the downstream left wingwall during the Level I assessment. The scour countermeasures at the site included type-1 stone fill (less than 12 inches diameter) at the downstream end of the downstream right wingwall, type-2 stone fill (less than 36 inches diameter) along the upstream right wingwall and upstream right bank, and type-3 stone fill (less than 48 inches diameter) at the downstream end of the downstream left wingwall. Additional details describing conditions at the site are included in the Level II Summary and Appendices D and E.

Scour depths and recommended rock rip-rap sizes were computed using the general guidelines described in Hydraulic Engineering Circular 18 (Richardson and others, 1995) for the 100- and 500-year discharges. In addition, the incipient roadway-overtopping discharge is determined and analyzed as another potential worst-case scour scenario. Total scour at a highway crossing is comprised of three components: 1) long-term streambed degradation; 2) contraction scour (due to accelerated flow caused by a reduction in flow area at a bridge) and; 3 ) local scour (caused by accelerated flow around piers and abutments). Total scour is the sum of the three components. Equations are available to compute depths for contraction and local scour and a summary of the results of these computations follows.

Contraction scour for all modelled flows ranged from 0.5 to $1.0 \mathrm{ft}$. The worst-case contraction scour occurred at the 500-year discharge. Abutment scour ranged from 8.0 to $11.8 \mathrm{ft}$. The worst-case abutment scour occurred at the 500-year discharge. Additional information on scour depths and depths to armoring are included in the section titled "Scour Results". Scoured-streambed elevations, based on the calculated scour depths, are presented in tables 1 and 2. A cross-section of the scour computed at the bridge is presented in figure 8. Scour depths were calculated assuming an infinite depth of erosive material and a homogeneous particle-size distribution.

It is generally accepted that the Froehlich and HIRE equations (abutment scour) give "excessively conservative estimates of scour depths" (Richardson and others, 1995, p. 47). Usually, computed scour depths are evaluated in combination with other information including (but not limited to) historical performance during flood events, the geomorphic stability assessment, existing scour protection measures, and the results of the hydraulic analyses. Therefore, scour depths adopted by VTAOT may differ from the computed values documented herein. 


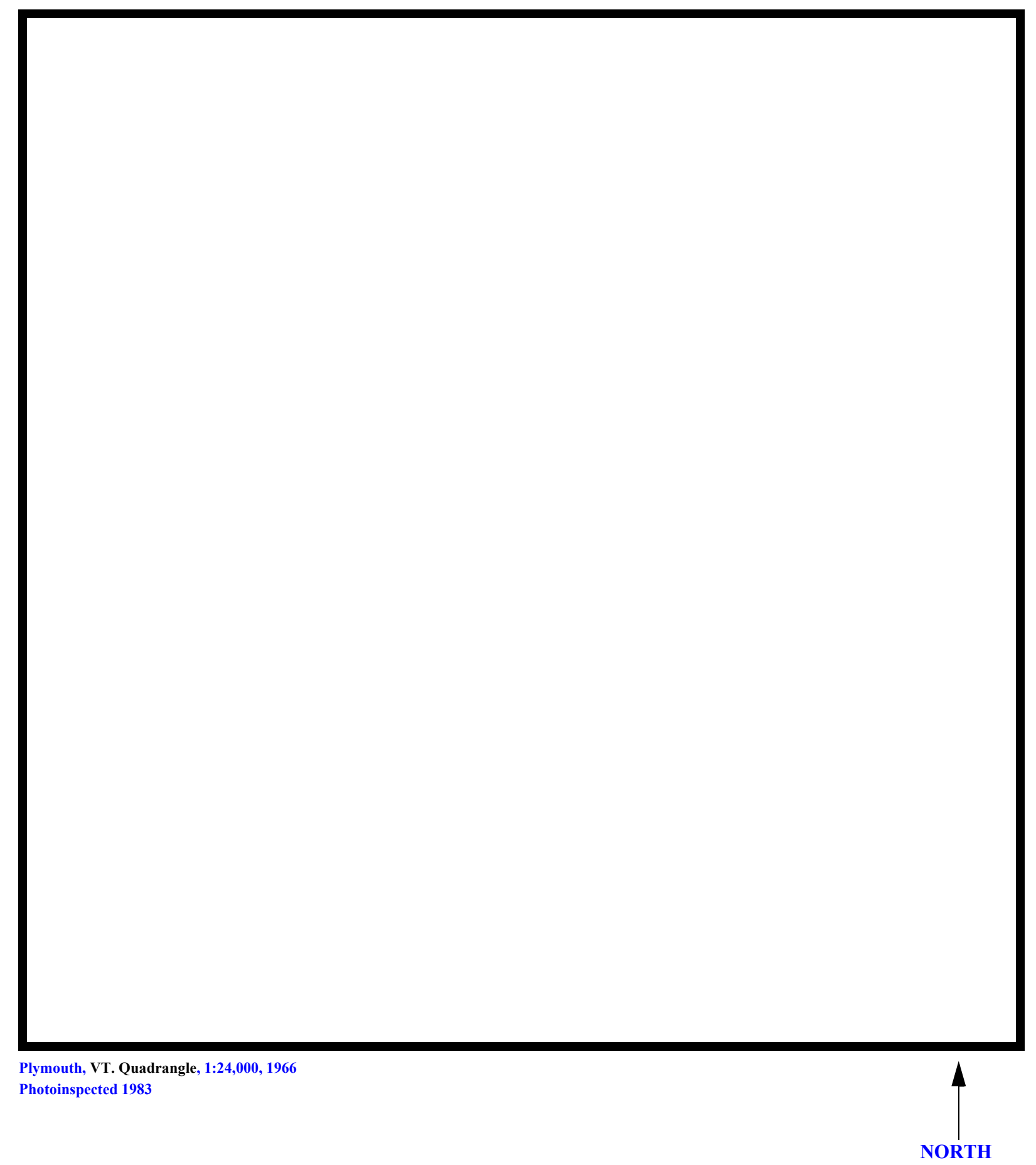

Figure 1. Location of study area on USGS 1:24,000 scale map. 
Figure 2. Location of study area on Vermont Agency of Transportation town highway map. 

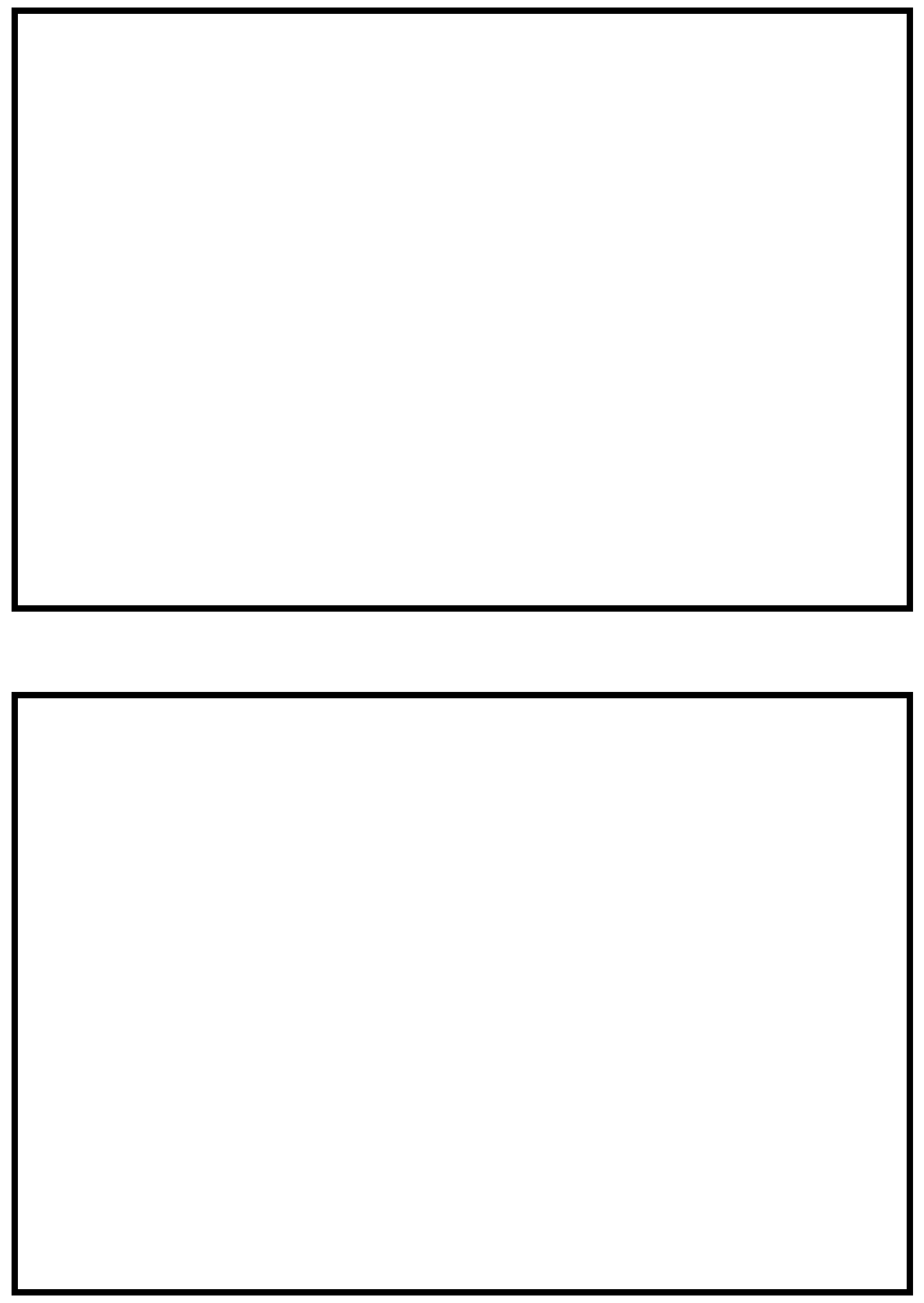

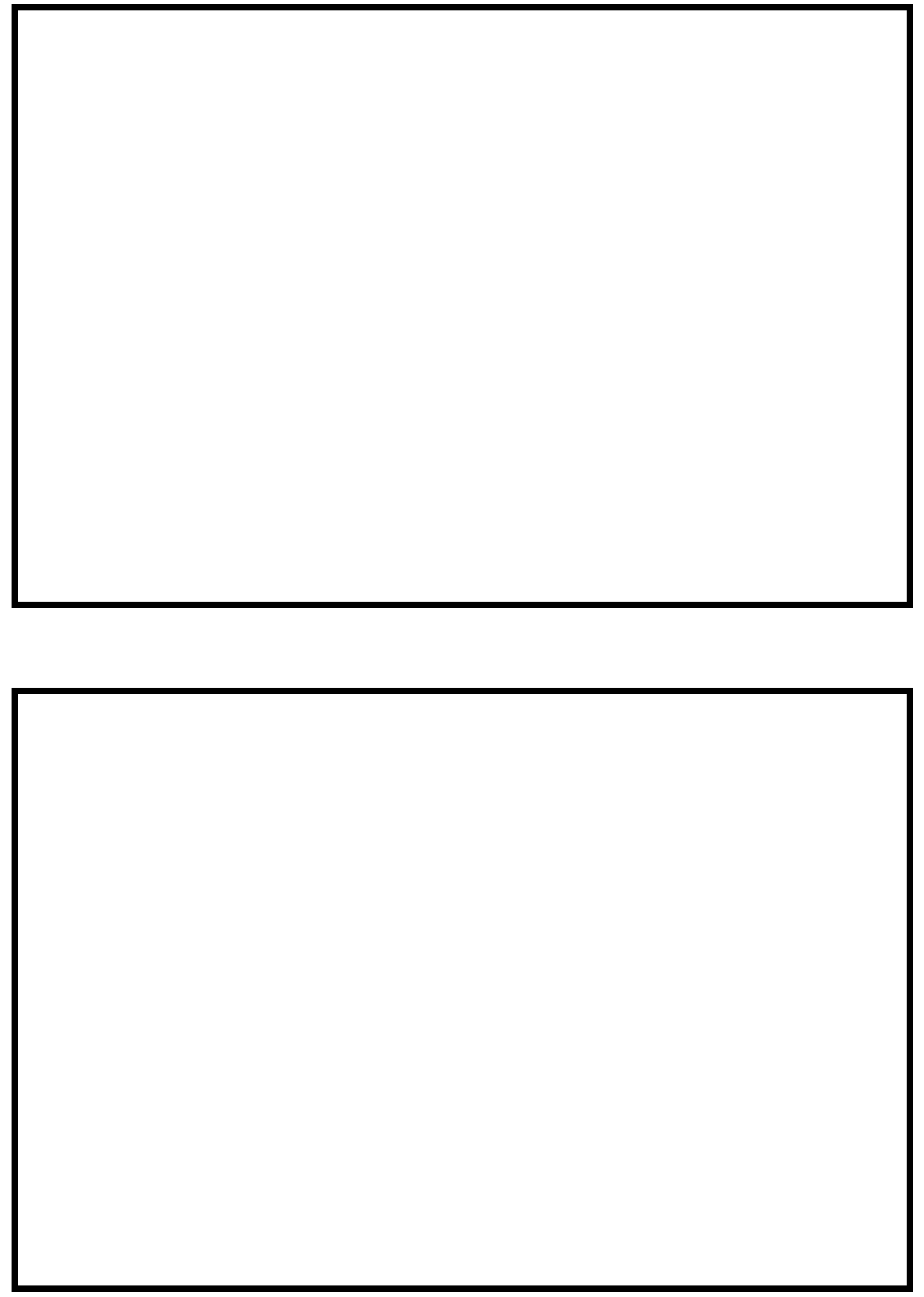


\section{LEVEL II SUMMARY}

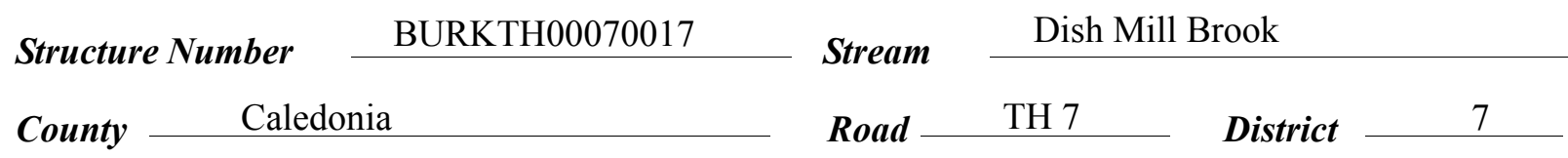

\section{Description of Bridge}

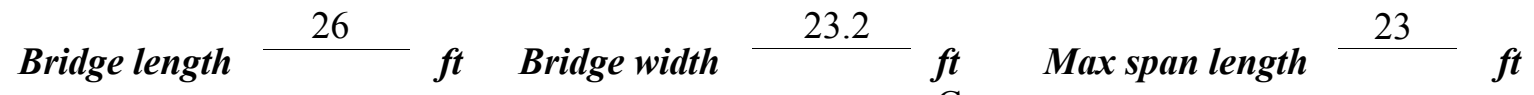
Alignment of bridge to road (on curve or straight)

\section{Abutment type} Vertical, concrete

Stone fill on abutment?

$$
\text { Yes }
$$

\section{Embankment type}

Curve

Dato af incnortion Type-1, at the downstream end of the downstream right wingwall.

namanintin.. af atan s fil

Type-2, along the upstream right wingwall and upstream right bank. Type-3, at the downstream

end of the downstream left wingwall.

Abutments and wingwalls are concrete. There is a one

and a half foot deep scour hole in front of the downstream end of the left abutment and

downstream left wingwall.

$$
\text { Yes }
$$

Is bridge skewed to flood flow according to Yes 'survey?

Angle

There is a moderate channel bend in the upstream reach. A cut-bank has developed in the location where the bend impacts the upstream left bank.

Debris accumulation on bridge at time of Level I or Level II site visit:

$$
\begin{gathered}
\text { Date of insnortion } \\
8 / 7 / 95 \\
\hline
\end{gathered}
$$

Level I

$$
8 / 7 / 95
$$

Level II

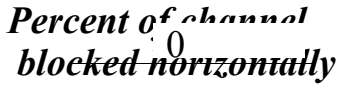

0
Percent of allonel
blocked verticatty

0 along the bank, some of which have already fallen in the channel upstream.

Potential for debris

None as of $8 / 7 / 95$.

Doscriho any, foaturos noar ar at tho hridoo that mav, affort flou, (includo ahsorvation dato) 


\section{Description of the Geomorphic Setting}

General topography The channel is located within a moderate relief valley.

Geomorphic conditions at bridge site: downstream (DS), upstream (US)

Date of inspection $\quad 8 / 7 / 95$

DS left: $\quad$ Moderately sloped channel bank

DS right: $\quad$ Steep valley wall

US left: $\quad$ Steep valley wall

US right: $\quad$ Moderately sloped channel bank

\section{Description of the Channel}

\begin{tabular}{|c|c|c|c|}
\hline \multirow[b]{2}{*}{ Average top width } & \multirow[b]{2}{*}{$\begin{array}{c}\boldsymbol{f} t \\
\text { Gravel/Cobble }\end{array}$} & \multirow[b]{2}{*}{ Average depth } & 3 \\
\hline & & & Sand/Gravel ${ }^{\boldsymbol{f t}}$ \\
\hline Predominant bed material & & Bank material & Sinuous with semi- \\
\hline âlluvial channél boundaries. & $\cdot \cdots$ & .. & \\
\hline
\end{tabular}

$\begin{array}{ll}\text { Vegetative co } & \text { Trees with shrubs and brush on the overbank } \\ \text { DS left: } & \text { Trees }\end{array}$

DS right: $\quad$ Trees

US left: $\quad$ Trees

US right: $\quad$ No

Do banks appear stable? The assessment of $8 / 7 / 95$ noted cut-banks on the upstream left bank, date downstream right bank and the downstream left bank.

None as of $8 / 7 / 95$.

Describe any obstructions in channel and date of observation. 


\title{
Hydrology
}

Drainage area $\quad 5.9 \quad \boldsymbol{m i}^{2}$

Percentage of drainage area in physiographic provinces: (approximate)

Physiographic province/section

New England/White Mountain
Percent of drainage area 100

\begin{abstract}
Is drainage area considered rural or urban?
Rural None.

urbanization:-

Describe any significant
\end{abstract}

Is there a USGS gage on the stream of interest?
USGS gage description

No

USGS gage description

USGS gage number

Gage drainage area $\mathrm{mi}^{2}$

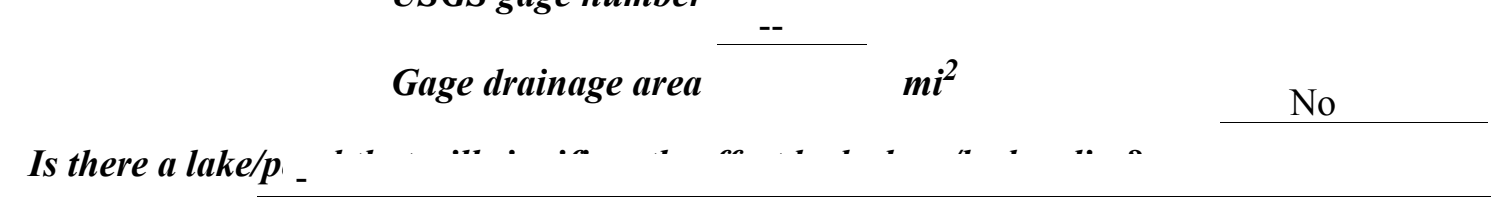

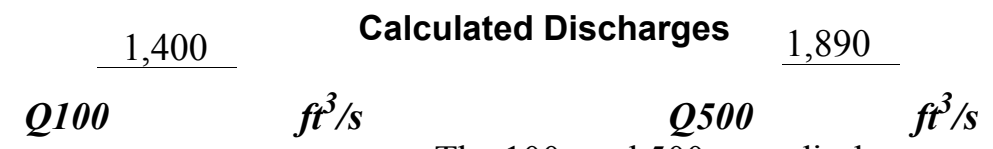

The 100- and 500-year discharges are based on a

drainage area relationship [(5.2/6.4)exp 0.67] with Flood Insurance Study values for Dish Mill Brook at the confluence with the East Branch Passumpsic River in Burke (Federal Emergency Management Agency, 1979). Dish Mill Brook enters the East Branch Passumpsic River downstream of this site and has a drainage area of 6.4 square miles at the confluence. The values used were within a range defined by flood frequency curves developed from several empirical methods (Benson, 1962; Johnson and Tasker, 1974; FHWA, 1983; Potter, 1957a\&b; Talbot, 1887). 


\section{Description of the Water-Surface Profile Model (WSPRO) Analysis}

Datum for WSPRO analysis (USGS survey, sea level, VTAOT plans)

USGS survey

Datum tie between USGS survey and VTAOT plans

None

Description of reference marks used to determine USGS datum. $\quad$ RM1 is a chiseled X on

top of the curb at the downstream right corner of the bridge (elev. $501.50 \mathrm{ft}$, arbitrary survey

datum). RM2 is a chiseled X on top of the curb at the upstream left corner of the bridge (elev.

$501.53 \mathrm{ft}$, arbitrary survey datum).

\section{Cross-Sections Used in WSPRO Analysis}

\begin{tabular}{|c|c|c|c|}
\hline${ }^{1}$ Cross-section & $\begin{array}{c}\text { Section } \\
\text { Reference } \\
\text { Distance } \\
\text { (SRD) in feet }\end{array}$ & $\begin{array}{c}{ }^{2} \text { Cross-section } \\
\text { development }\end{array}$ & Comments \\
\hline EXIT1 & -23 & 1 & Exit section \\
\hline FULLV & 0 & 2 & $\begin{array}{l}\text { Downstream Full-valley } \\
\text { section (Templated from } \\
\text { EXIT1) }\end{array}$ \\
\hline BRIDG & 0 & 1 & Bridge section \\
\hline RDWAY & 12 & 1 & Road Grade section \\
\hline APPRO & 47 & 1 & Approach section \\
\hline
\end{tabular}

${ }^{1}$ For location of cross-sections see plan-view sketch included with Level I field form, Appendix E. For more detail on how cross-sections were developed see WSPRO input file. 


\section{Data and Assumptions Used in WSPRO Model}

Hydraulic analyses of the reach were done by use of the Federal Highway Administration's WSPRO step-backwater computer program (Shearman and others, 1986, and Shearman, 1990). The analyses reported herein reflect conditions existing at the site at the time of the study. Furthermore, in the development of the model it was necessary to assume no accumulation of debris or ice at the site. Results of the hydraulic model are presented in the Bridge Hydraulic Summary, Appendix B, and figure 7.

Channel roughness factors (Manning's " $n$ ") used in the hydraulic model were estimated using field inspections at each cross section following the general guidelines described by Arcement and Schneider (1989). Final adjustments to the values were made during the modelling of the reach. Channel " $n$ " values for the reach ranged from 0.045 to 0.065 , and the overbank "n" value was 0.070 .

Critical depth at the exit section (EXIT1) was assumed as the starting water surface. Normal depth was computed by use of the slope-conveyance method outlined in the user's manual for WSPRO (Shearman, 1990) and resulted in a supercritical solution. Because normal depth was within $0.3 \mathrm{ft}$ of critical depth, the critical water surface was assumed to be a satisfactory starting water surface. The slope used was $0.0381 \mathrm{ft} / \mathrm{ft}$, which was estimated from surveyed thalweg points downstream of the bridge.

The surveyed approach section (APPRO) was one bridge length upstream of the upstream face as recommended by Shearman and others (1986). This location provides a consistent method for determining scour variables. 


\section{Bridge Hydraulics Summary}

\begin{tabular}{llll} 
Average bridge embankment elevation & 501.5 \\
\cline { 3 - 3 } Average low steel elevation & 498.5 & $\boldsymbol{f t}$
\end{tabular}

100-year discharge $\quad 1,400 \quad \mathrm{ft}^{3} / \mathrm{s}$

Water-surface elevation in bridge opening $498.5 \quad f t$

Road overtopping? ___ Yes Discharge over road ___ $28 \quad \mathrm{ft}^{3} / \mathrm{s}$

\begin{tabular}{lll} 
Area of flow in bridge opening & $142 \quad \mathrm{ft}^{2}$ \\
\cline { 2 - 3 } Average velocity in bridge opening & $9.6 \quad \mathrm{ft} / \mathrm{s}$
\end{tabular}

Maximum WSPRO tube velocity at bridge $\quad 11.6 \mathrm{ft} / \mathrm{s}$

Water-surface elevation at Approach section with bridge $\quad 501.2$

Water-surface elevation at Approach section without bridge $\quad 497.9$

Amount of backwater caused by bridge

3.3 it

500-year discharge $\quad 1,890 \quad \mathrm{ft}^{3} / \mathrm{s}$

Water-surface elevation in bridge opening $\quad 498.5 \mathrm{ft}$

Road overtopping? ___ Yes Discharge over road _ $458,3 / 5$

Area of flow in bridge opening $\quad 142 \quad \mathrm{ft}^{2}$

Average velocity in bridge opening $10.2 \mathrm{ft} / \mathrm{s}$

Maximum WSPRO tube velocity at bridge 12.3 , 's

Water-surface elevation at Approach section with bridge 501.7

Water-surface elevation at Approach section without bridge $\quad 498.6$

Amount of backwater caused by bridge $3.1, t$

Incipient overtopping discharge $\quad 1,350 \mathrm{ft}^{3} / \mathrm{s}$

Water-surface elevation in bridge opening $498.5 \quad$ t

\begin{tabular}{llll} 
Area of flow in bridge opening & 142 & $\boldsymbol{f t}^{\mathbf{2}}$ & \\
\cline { 2 - 3 } Average velocity in bridge opening & $9.5 \quad \mathrm{ft} / \mathrm{s}$
\end{tabular}

Maximum WSPRO tube velocity at bridge $\quad 11.5 \mathrm{ft} / \mathrm{s}$

Water-surface elevation at Approach section with bridge

Water-surface elevation at Approach section without bridge

Amount of backwater caused by bridge $\quad$\begin{tabular}{l}
3.2 it \\
\hline
\end{tabular}

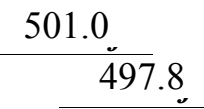




\section{Scour Analysis Summary}

\section{Special Conditions or Assumptions Made in Scour Analysis}

Scour depths were computed using the general guidelines described in Hydraulic Engineering Circular 18 (Richardson and others, 1995). Scour depths were calculated assuming an infinite depth of erosive material and a homogeneous particle-size distribution. The results of the scour analysis are presented in tables 1 and 2 and a graph of the scour depths is presented in figure 8 .

At this site, the 100-year, 500-year and incipient roadway-overtopping discharges resulted in unsubmerged orifice flow. Contraction scour at bridges with orifice flow is best estimated by use of the Chang pressure-flow scour equation (oral communication, J. Sterling Jones, October 4, 1996). Thus, contraction scour for these discharges was computed by use of the Chang equation (Richardson and others, 1995, p. 145-146). The computed streambed armoring depths suggest that armoring will not limit the depth of contraction scour.

For comparison, contraction scour for the discharges resulting in orifice flow was also computed by use of the Laursen clear-water contraction scour equation (Richardson and others, 1995, p. 32, equation 20) and the Umbrell pressure-flow equation (Richardson and others, 1995, p. 144) and presented in Appendix F. Furthermore, for those discharges resulting in unsubmerged orifice flow, contraction scour was computed by substituting estimates for the depth of flow at the downstream bridge face in the contraction scour equations. Results with respect to these substitutions are provided in Appendix F.

Abutment scour for the right abutment was computed by use of the Froehlich equation (Richardson and others, 1995, p. 48, equation 28). Variables for the Froehlich equation include the Froude number of the flow approaching the embankments, the length of the embankment blocking flow, and the depth of flow approaching the embankment less any roadway overtopping.

Scour at the left abutment was computed by use of the HIRE equation (Richardson and others, 1995, p. 49, equation 29) because the HIRE equation is recommended when the length to depth ratio of the embankment blocking flow exceeds 25 . The variables used by the HIRE abutment-scour equation are defined the same as those defined for the Froehlich abutment-scour equation. 


\section{Scour Results}

$$
\text { 100-yr discharge 500-yr discharge }
$$

Contraction scour:

Main channel

Live-bed scour

Clear-water scour

Depth to armoring

Left overbank

Right overbank

Local scour:

Abutment scour

Left abutment

Right abutment

Pier scour

Pier 1

Pier 2

Pier 3

(Scour depths in feet)

overtopping discharge
Incipient 


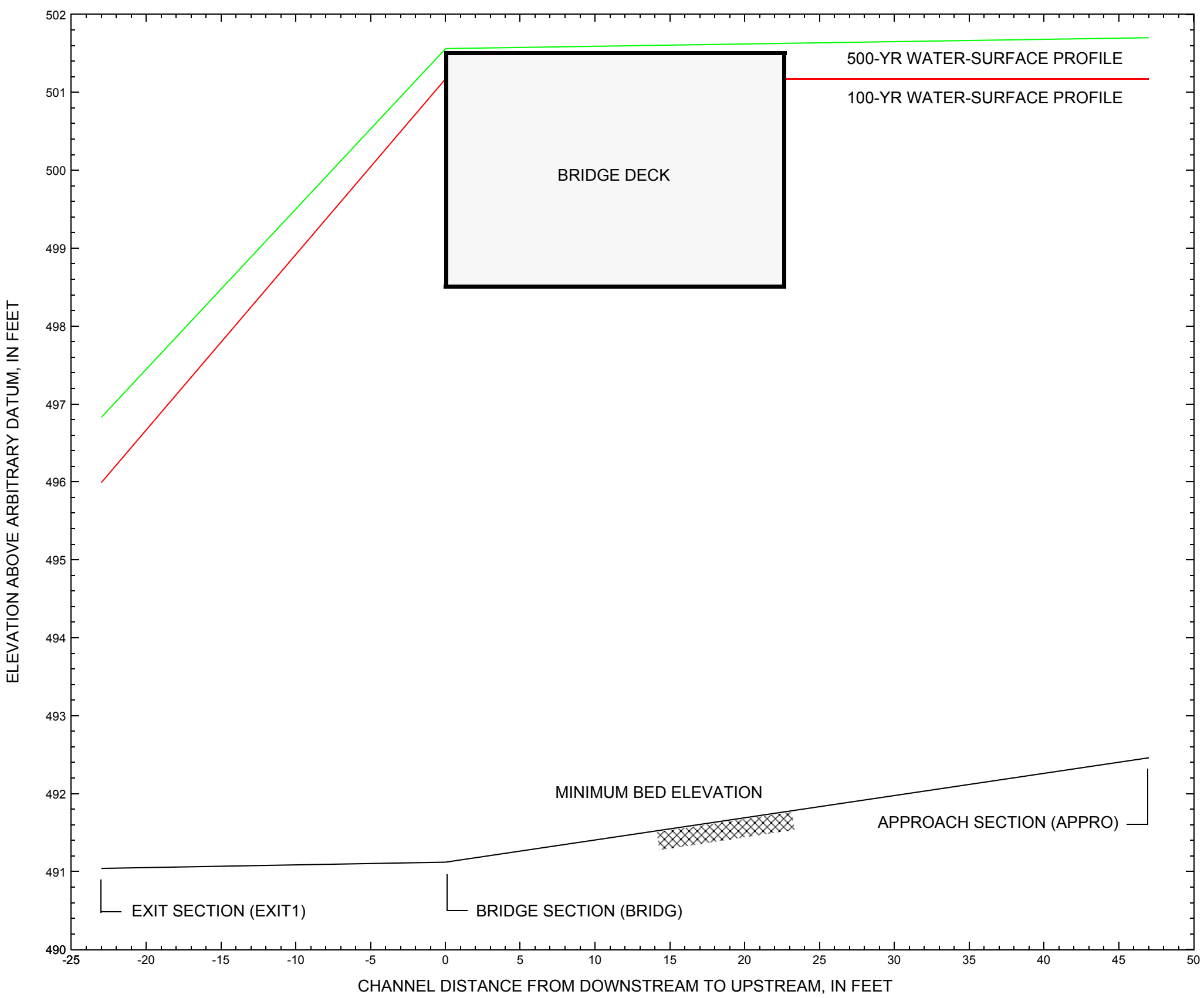

Figure 7. Water-surface profiles for the 100- and 500-yr discharges at structure BURKTH00070017 on Town Highway 7, crossing Dish Mill Brook, Burke, Vermont. 


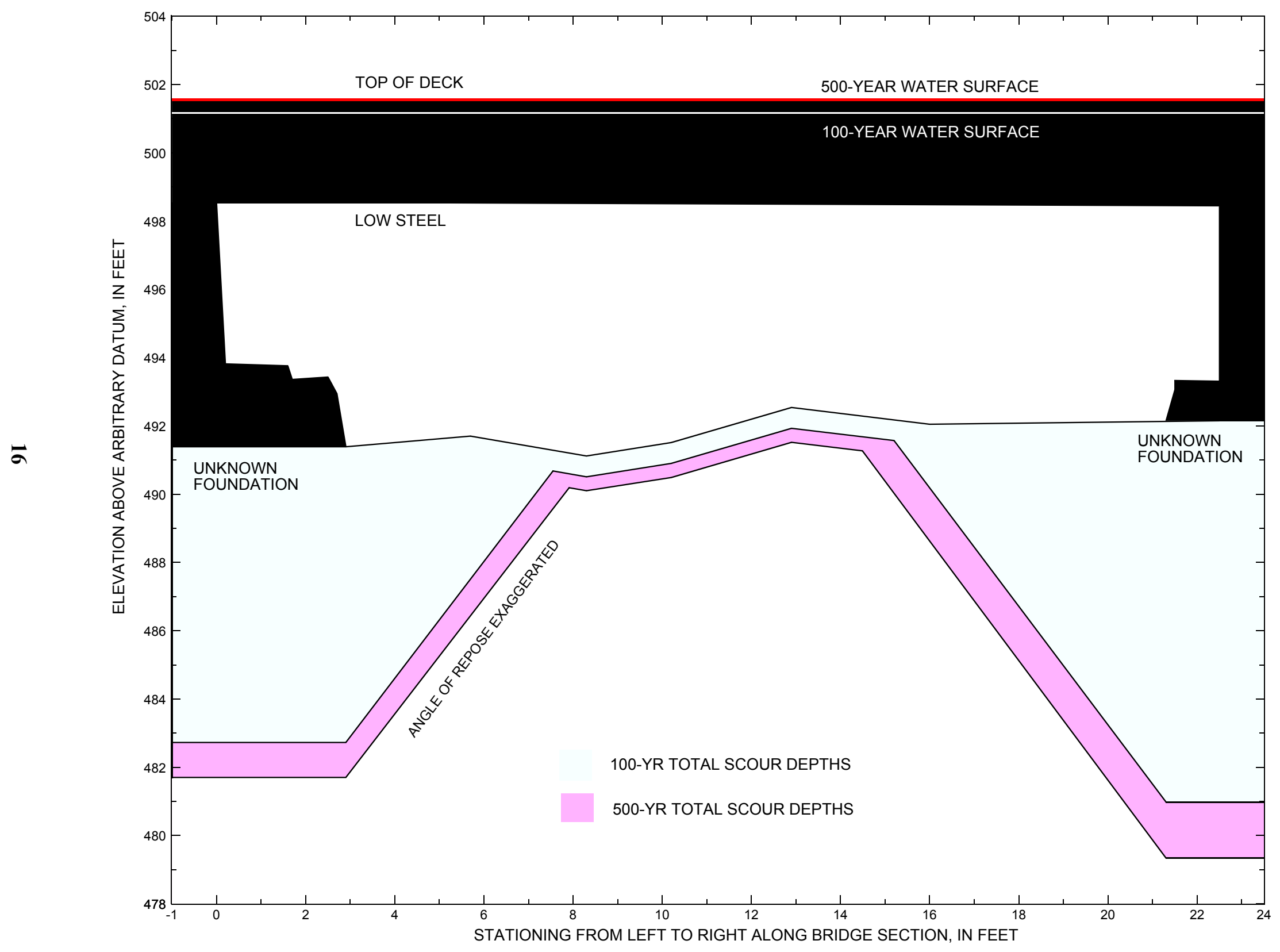

Figure 8. Scour elevations for the 100-yr and 500-yr discharges at structure BURKTH00070017 on Town Highway 7, crossing Dish Mill Brook, Burke, Vermont. 
Table 1. Remaining footing/pile depth at abutments for the 100-year discharge at structure BURKTH00070017 on Town Highway 7 , crossing Dish Mill Brook, Burke, Vermont.

[VTAOT, Vermont Agency of Transportation; --, no data]

\begin{tabular}{|c|c|c|c|c|c|c|c|c|c|c|c|}
\hline Description & Station $^{1}$ & $\begin{array}{l}\text { VTAOT } \\
\text { minimum } \\
\text { low-chord } \\
\text { elevation } \\
\text { (feet) }\end{array}$ & $\begin{array}{c}\text { Surveyed } \\
\text { minimum } \\
\text { low-chord } \\
\text { elevation } \\
\text { (feet) }\end{array}$ & $\begin{array}{c}\text { Bottom of } \\
\text { footing/pile } \\
\text { elevation } \\
\text { (feet) }\end{array}$ & $\begin{array}{l}\text { Channel } \\
\text { elevation at } \\
\text { abutment/ } \\
\text { pier }^{2} \\
\text { (feet) }\end{array}$ & $\begin{array}{l}\text { Contraction } \\
\text { scour depth } \\
\text { (feet) }\end{array}$ & $\begin{array}{l}\text { Abutment } \\
\text { scour } \\
\text { depth } \\
\text { (feet) }\end{array}$ & $\begin{array}{l}\text { Pier } \\
\text { scour } \\
\text { depth } \\
\text { (feet) }\end{array}$ & $\begin{array}{l}\text { Depth of } \\
\text { total scour } \\
\text { (feet) }\end{array}$ & $\begin{array}{c}\text { Elevation of } \\
\text { scour }^{2} \\
\text { (feet) }\end{array}$ & $\begin{array}{c}\text { Remaining } \\
\text { footing/pile } \\
\text { depth } \\
\text { (feet) }\end{array}$ \\
\hline \multicolumn{12}{|c|}{100 -yr. discharge is 1,400 cubic-feet per second } \\
\hline Left abutment & 0.0 & -- & 498.5 & -- & 491.4 & 0.6 & 8.1 & -- & 8.7 & 482.7 & -- \\
\hline Right abutment & 22.5 & -- & 498.4 & -- & 492.2 & 0.6 & 10.6 & -- & 11.2 & 481.0 & -- \\
\hline
\end{tabular}

1.Measured along the face of the most constricting side of the bridge.

2.Arbitrary datum for this study.

Table 2. Remaining footing/pile depth at abutments for the 500-year discharge at structure BURKTH00070017 on Town Highway 7, crossing Dish Mill Brook, Burke, Vermont. [VTAOT, Vermont Agency of Transportation; --, no data]

\begin{tabular}{|c|c|c|c|c|c|c|c|c|c|c|c|}
\hline Description & Station $^{1}$ & $\begin{array}{l}\text { VTAOT } \\
\text { minimum } \\
\text { low-chord } \\
\text { elevation } \\
\text { (feet) }\end{array}$ & $\begin{array}{l}\text { Surveyed } \\
\text { minimum } \\
\text { low-chord } \\
\text { elevation } \\
\text { (feet) }\end{array}$ & $\begin{array}{c}\text { Bottom of } \\
\text { footing/pile } \\
\text { elevation }{ }^{2} \\
\text { (feet) }\end{array}$ & $\begin{array}{c}\text { Channel } \\
\text { elevation at } \\
\text { abutment/ } \\
\text { pier }^{2} \\
\text { (feet) }\end{array}$ & $\begin{array}{l}\text { Contraction } \\
\text { scour depth } \\
\text { (feet) }\end{array}$ & $\begin{array}{l}\text { Abutment } \\
\text { scour } \\
\text { depth } \\
\text { (feet) }\end{array}$ & $\begin{array}{l}\text { Pier } \\
\text { scour } \\
\text { depth } \\
\text { (feet) }\end{array}$ & $\begin{array}{l}\text { Depth of } \\
\text { total scour } \\
\text { (feet) }\end{array}$ & $\begin{array}{c}\text { Elevation of } \\
\text { scour }^{2} \\
\text { (feet) }\end{array}$ & $\begin{array}{c}\text { Remaining } \\
\text { footing/pile } \\
\text { depth } \\
\text { (feet) }\end{array}$ \\
\hline \multicolumn{12}{|c|}{500 -yr. discharge is 1,890 cubic-feet per second } \\
\hline Left abutment & 0.0 & -- & 498.5 & -- & 491.4 & 1.0 & 8.7 & -- & 9.7 & 481.7 & -- \\
\hline Right abutment & 22.5 & -- & 498.4 & -- & 492.2 & 1.0 & 11.8 & -- & 12.8 & 479.4 & -- \\
\hline
\end{tabular}

1.Measured along the face of the most constricting side of the bridge.

2.Arbitrary datum for this study. 


\section{SELECTED REFERENCES}

Arcement, G.J., Jr., and Schneider, V.R., 1989, Guide for selecting Manning's roughness coefficients for natural channels and flood plains:

U.S. Geological Survey Water-Supply Paper 2339, 38 p.

Barnes, H.H., Jr., 1967, Roughness characteristics of natural channels: U.S. Geological Survey Water-Supply Paper 1849,213 p.

Benson, M. A., 1962, Factors Influencing the Occurrence of Floods in a Humid Region of Diverse Terrain: U.S. Geological Survey WaterSupply Paper 1580-B, 64 p.

Brown, S.A. and Clyde, E.S., 1989, Design of riprap revetment: Federal Highway Administration Hydraulic Engineering Circular No. 11, Publication FHWA-IP-89-016, 156 p.

Federal Highway Administration, 1983, Runoff estimates for small watersheds and development of sound design: Federal Highway Administration Report FHWA-RD-77-158.

Federal Highway Administration, 1993, Stream Stability and Scour at Highway Bridges: Participant Workbook: Federal Highway Administration Report FHWA-HI-91-011.

Federal Emergency Management Agency, 1979, Flood Insurance Study, Town of Burke, Caledonia County, Vermont: Washington, D.C., December 1979.

Froehlich, D.C., 1989, Local scour at bridge abutments in Ports, M.A., ed., Hydraulic Engineering--Proceedings of the 1989 National Conference on Hydraulic Engineering: New York, American Society of Civil Engineers, p. 13-18.

Hayes, D.C.,1993, Site selection and collection of bridge-scour data in Delaware, Maryland, and Virginia: U.S. Geological Survey WaterResources Investigation Report 93-4017, 23 p.

Interagency Advisory Committee on Water Data, 1982, Guidelines for determining flood flow frequency: U.S. Geological Survey, Bulletin 17B of the Hydrology Subcommittee, 190 p.

Johnson, C.G. and Tasker, G.D.,1974, Progress report on flood magnitude and frequency of Vermont streams: U.S. Geological Survey OpenFile Report 74-130, 37 p.

Lagasse, P.F., Schall, J.D., Johnson, F., Richardson, E.V., Chang, F., 1995, Stream Stability at Highway Structures: Federal Highway Administration Hydraulic Engineering Circular No. 20, Publication FHWA-IP-90-014, 144 p.

Laursen, E.M., 1960, Scour at bridge crossings: Journal of the Hydraulics Division, American Society of Civil Engineers, v. 86, no. HY2, p. 39-53.

Potter, W. D., 1957a, Peak rates of runoff in the Adirondack, White Mountains, and Maine woods area, Bureau of Public Roads

Potter, W. D., 1957b, Peak rates of runoff in the New England Hill and Lowland area, Bureau of Public Roads

Richardson, E.V. and Davis, S.R., 1995, Evaluating scour at bridges: Federal Highway Administration Hydraulic Engineering Circular No. 18, Publication FHWA-IP-90-017, 204 p.

Richardson, E.V., Simons, D.B., and Julien, P.Y., 1990, Highways in the river environment: Federal Highway Administration Publication FHWA-HI-90-016.

Ritter, D.F., 1984, Process Geomorphology: W.C. Brown Co., Debuque, Iowa, 603 p.

Shearman, J.O., 1990, User's manual for WSPRO--a computer model for water surface profile computations: Federal Highway Administration Publication FHWA-IP-89-027, 187 p.

Shearman, J.O., Kirby, W.H., Schneider, V.R., and Flippo, H.N., 1986, Bridge waterways analysis model; research report: Federal Highway Administration Publication FHWA-RD-86-108, 112 p.

Talbot, A.N., 1887, The determination of water-way for bridges and culverts.

U.S. Department of Transportation, 1993, Stream stability and scour at highway bridges, Participant Workbook: Federal Highway Administration Publication FHWA HI-91-011.

U.S. Geological Survey, 1988, Burke Mountain, Vermont 7.5 Minute Series quadrangle map: U.S. Geological Survey Topographic Maps, Scale 1:24,000. 


\section{APPENDIX A: \\ WSPRO INPUT FILE}




\section{WSPRO INPUT FILE}

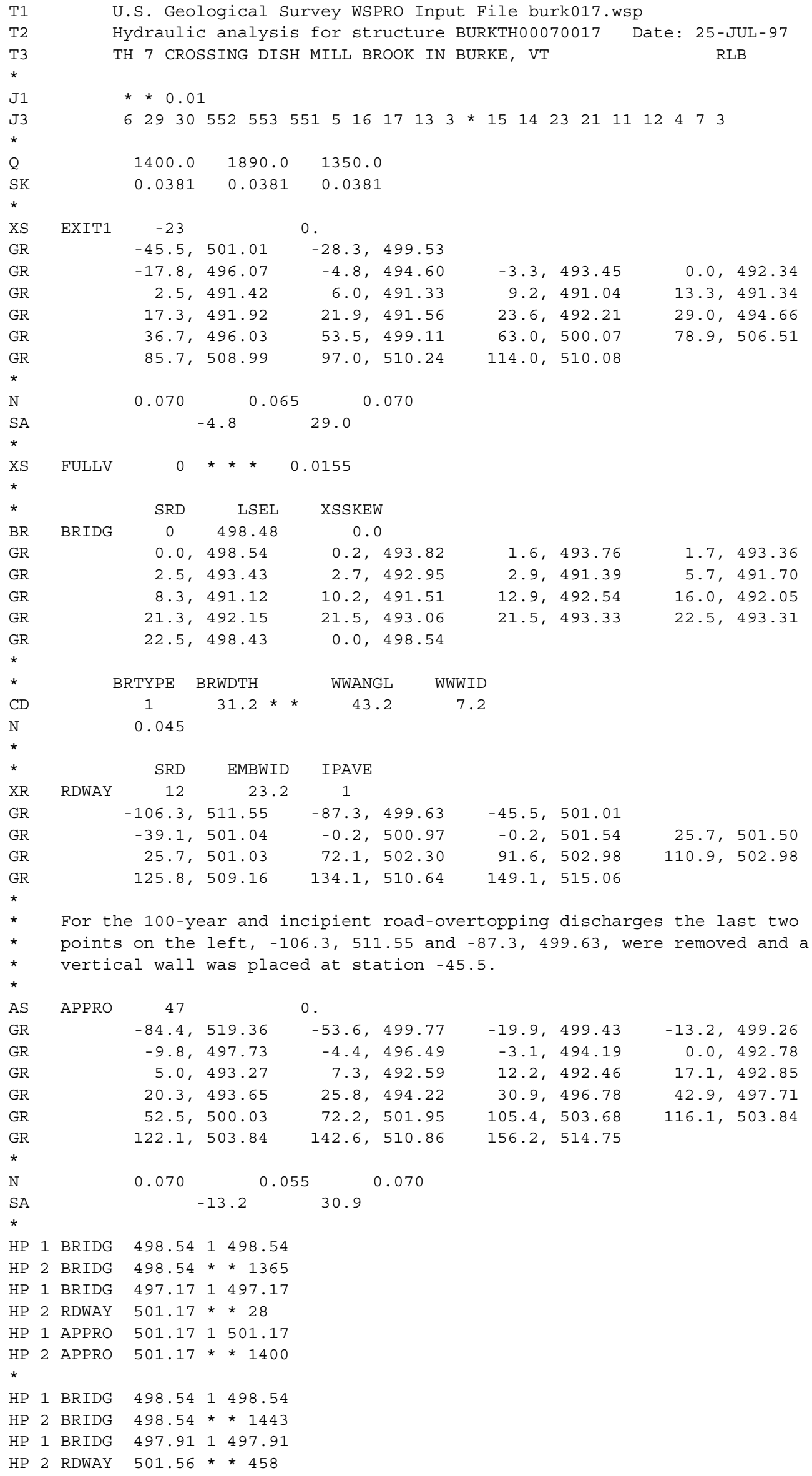




\section{APPENDIX B: \\ WSPRO OUTPUT FILE}


WSPRO OUTPUT FILE

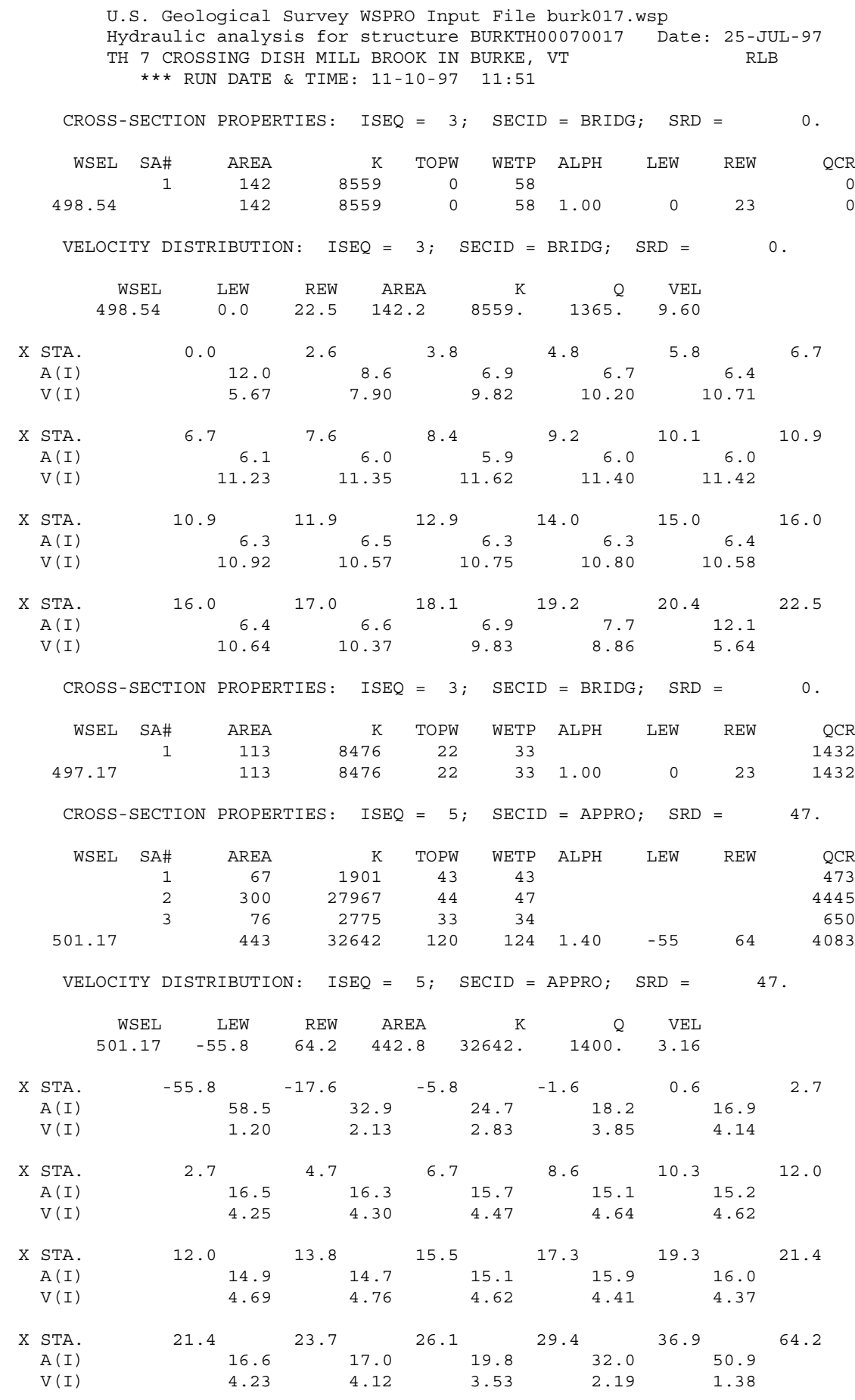


WSPRO OUTPUT FILE (continued)

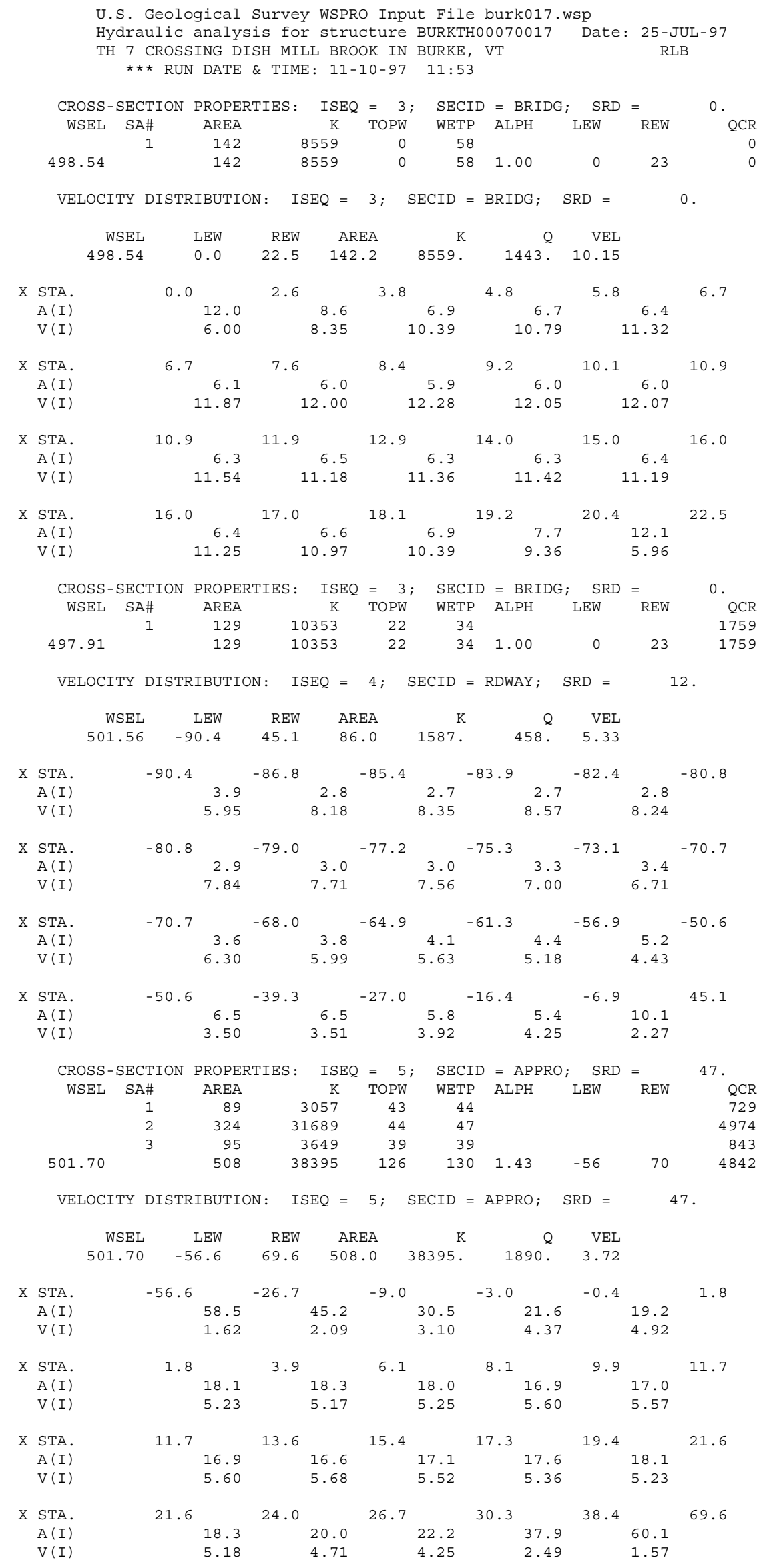


WSPRO OUTPUT FILE (continued)

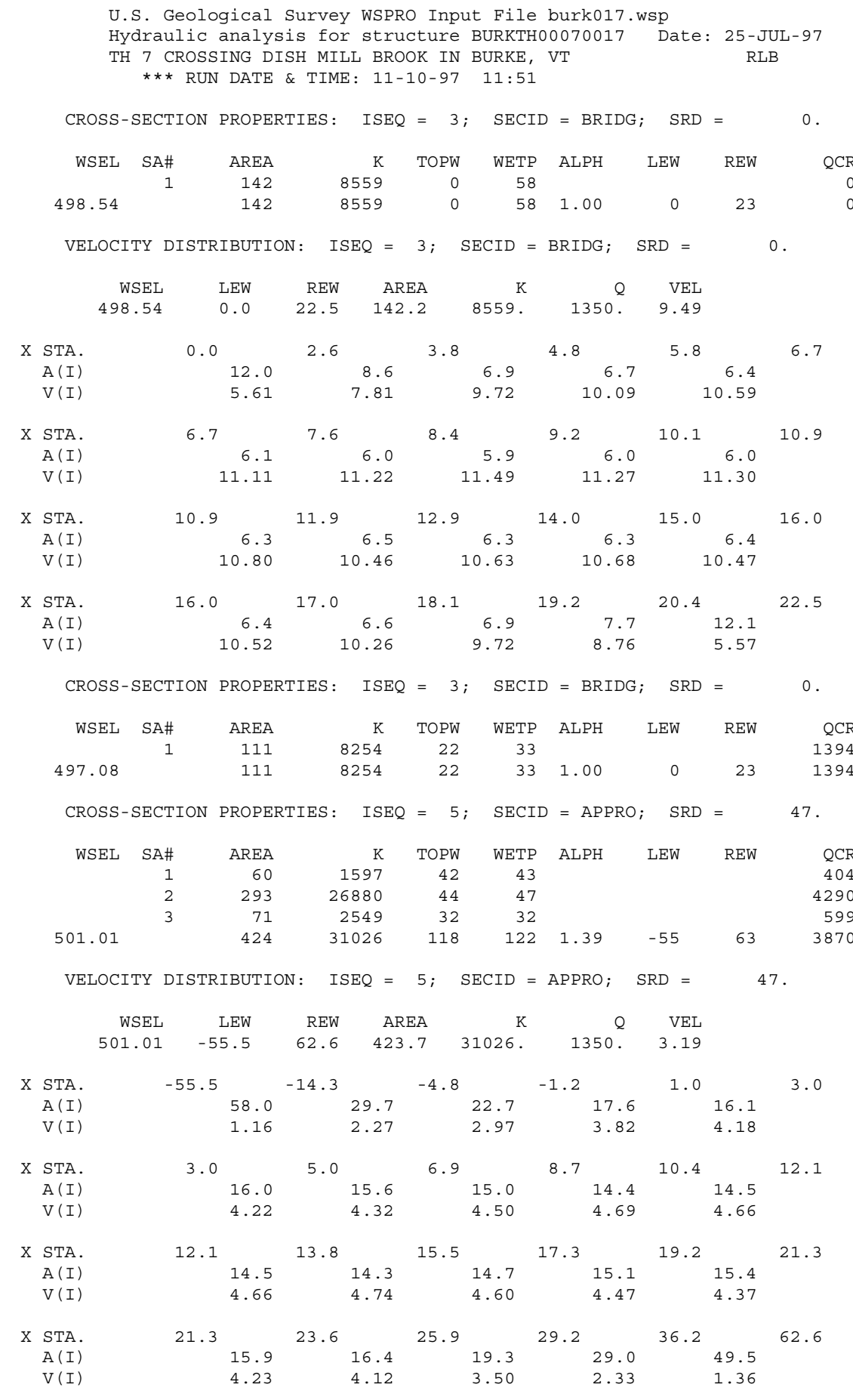


WSPRO OUTPUT FILE (continued)

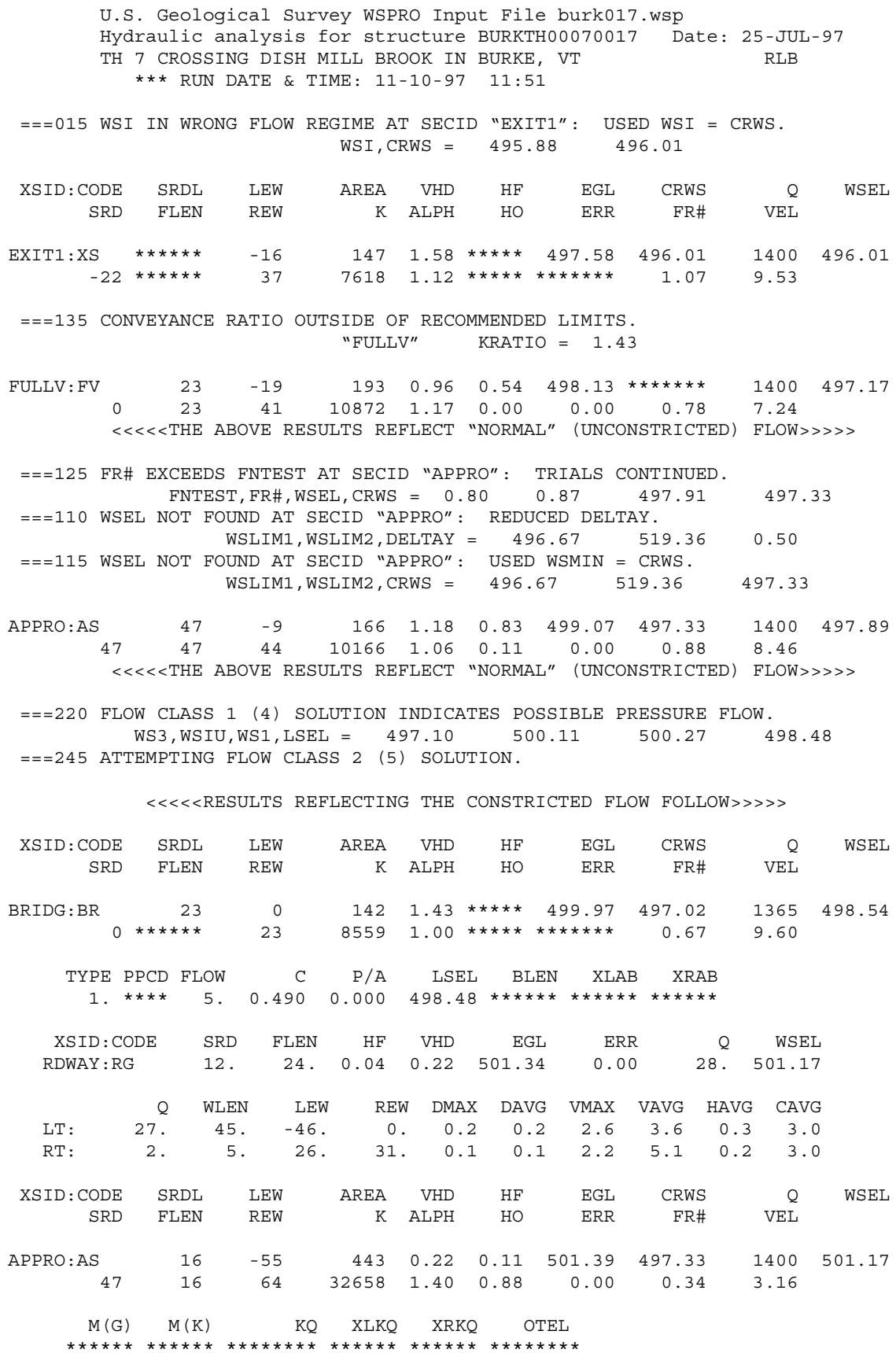


WSPRO OUTPUT FILE (continued)

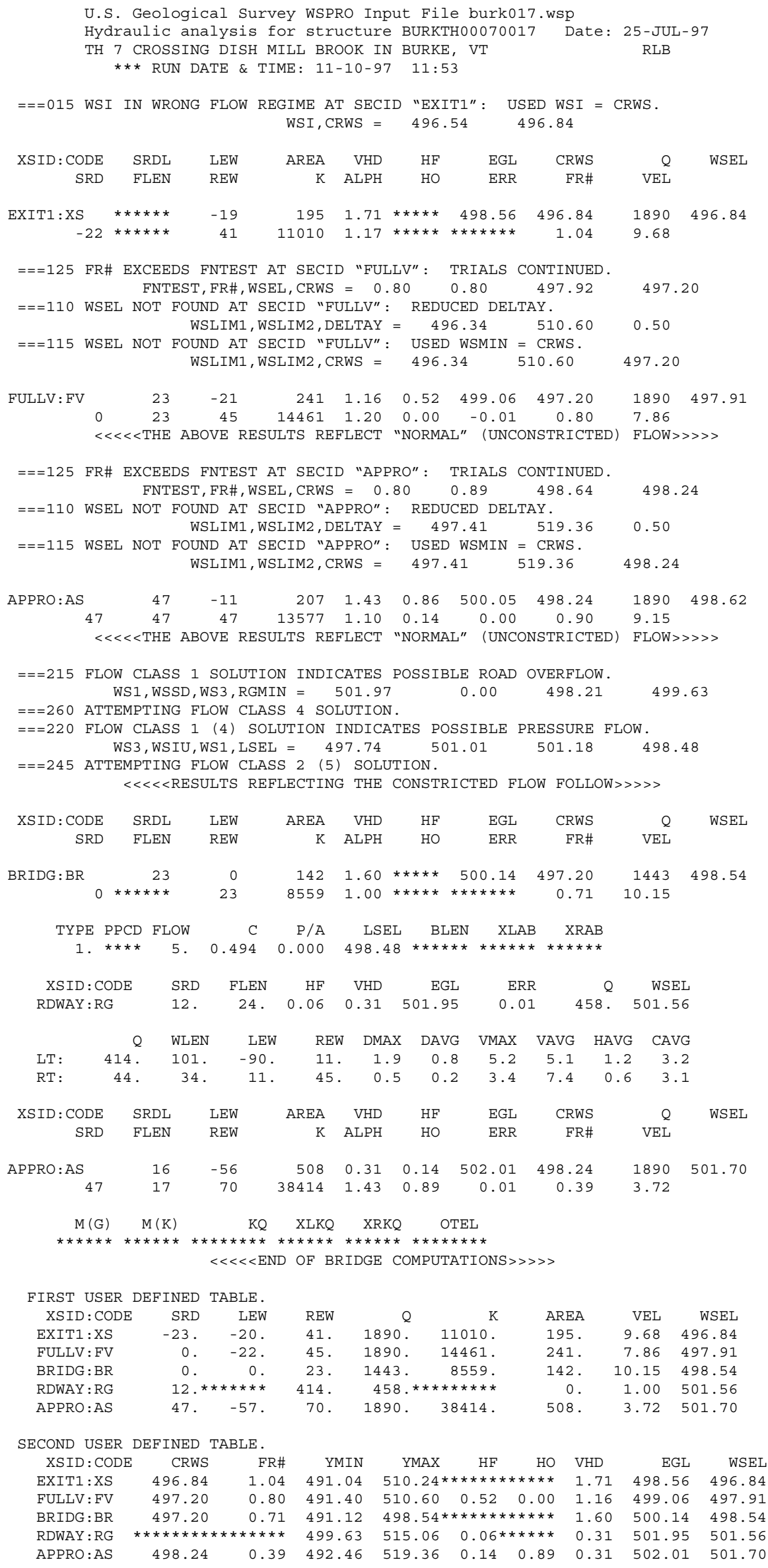


WSPRO OUTPUT FILE (continued)

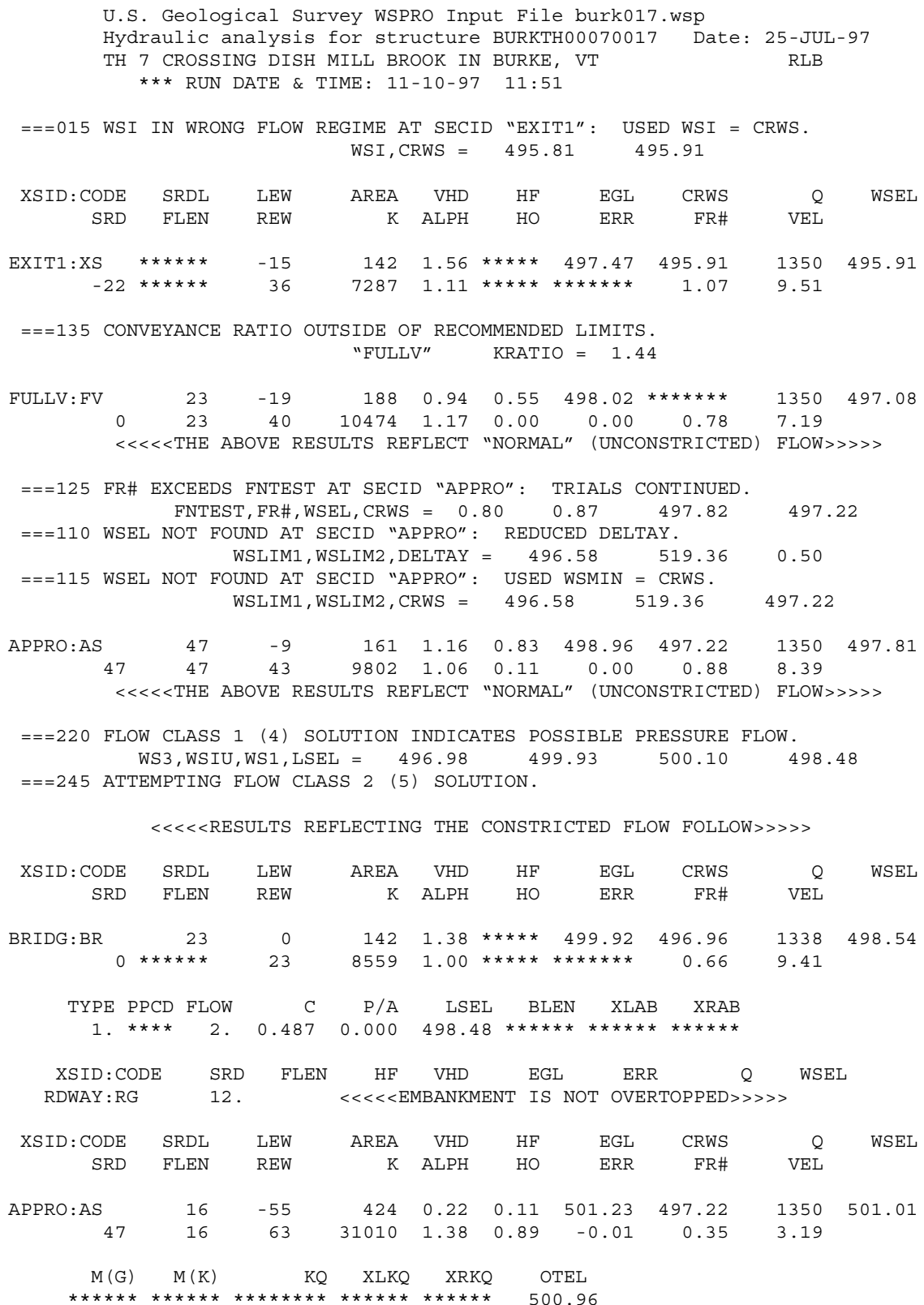




\section{APPENDIX C:}

\section{BED-MATERIAL PARTICLE-SIZE DISTRIBUTION}




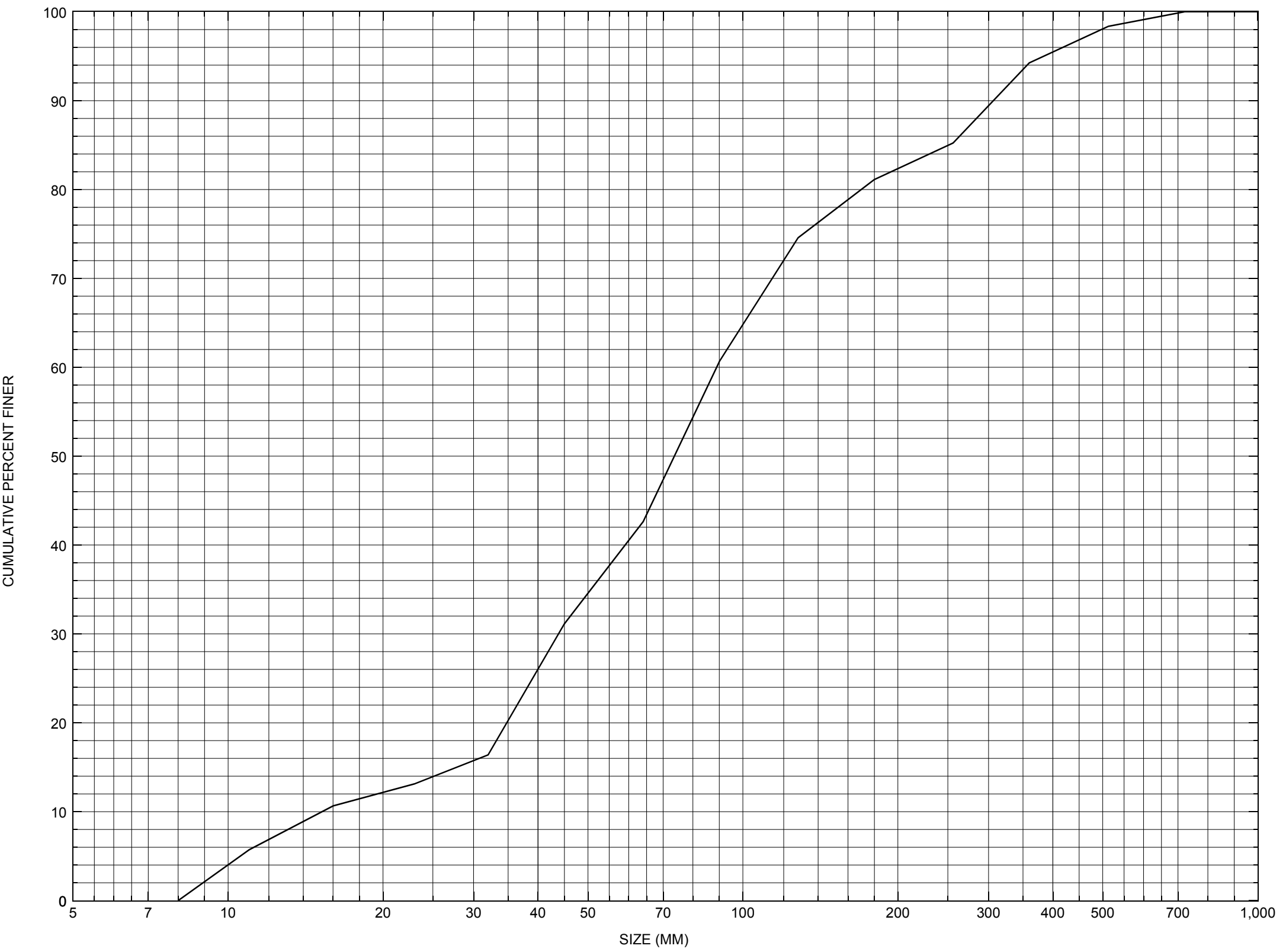

Appendix C. Bed material particle-size distribution for a pebble count in the channel approach of structure BURKTH00070017, in Burke, Vermont. 


\section{APPENDIX D: \\ HISTORICAL DATA FORM}




\section{Structure Number BURKTH00070017}

\section{General Location Descriptive}

Data collected by (First Initial, Full last name) $\underline{\text { E }}$. BOEHMLER

Date $(M M / D D / Y Y) \_\mathbf{0 3} / \underline{24} / \underline{95}$

Highway District Number (I - 2; nn) $\mathbf{0 7}$

Town (FIPS place code; I - 4; nnnnn) $\mathbf{1 0 4 5 0}$

Waterway ( $I$ - 6) DISH MILL BROOK

Route Number $\underline{\text { TH007 }}$

Topographic Map Burke.Mountain

Latitude (I - 16; nnnn.n) $\mathbf{4 4 3 5 4}$
County (FIPS county code; I - 3; nnn)

Mile marker (I - 11; nnn.nnn) $\mathbf{0 0 0 0 0 0}$

Road Name (I - 7): -

Vicinity (I - 9) 0.6 MI JCT TH 7 + VT 114

Hydrologic Unit Code: $\mathbf{0 1 0 8 0 1 0 2}$

Longitude (i - 17; nnnnn.n) $\mathbf{7 1 5 5 8}$

\section{Select Federal Inventory Codes}

FHWA Structure Number (I - 8) $\mathbf{1 0 0 3 0 2 0 0 1 7 0 3 0 2}$

Maintenance responsibility $(I-21 ; n n) \quad \mathbf{0 3}$

Year built (I - 27; YYYY) 1929

Average daily traffic, ADT (I - 29; nnnnnn) 000800

Year of ADT (I - 30; YY) $\mathbf{9 2}$

Opening skew to Roadway $(I-34 ; n n) \quad \mathbf{0 0}$

Operational status $(I-41 ; X) \quad \mathbf{A}$

Structure type (I - 43; nnn) $\mathbf{3 0 2}$

Approach span structure type $(I-44 ; n n n) \quad \mathbf{0 0 0}$

Number of spans (I - 45; nnn) $\mathbf{0 0 1}$

Number of approach spans (I - 46; nnnn) $\mathbf{0 0 0 0}$

Comments:

The structural inspection report of 10/31/94 indicates the structure is a steel stringer type bridge with a concrete deck. The abutment walls and wingwalls are concrete. Both wingwalls on the right abutment are cracked off vertically at the corners where the abutment wall meets both wingwalls. The embankment area between the wingwalls and the roadway surface have been paved to prevent further erosion. Riprap is reported as added in front of the right upstream wingwall to help stabilize it. Some of the pavement has broken away and eroded from the embankment at this wingwall. The right abutment footing is exposed and has cracked vertically in a couple of places. The left abutment reportedly (Continued, page 33) 


\section{Bridge Hydrologic Data}

Is there hydrologic data available? $\mathbf{N}$ if No, type ctrl- $n$ VTAOT Drainage area $\left(m i^{2}\right)$ : -

Terrain character:

Stream character \& type: -

Streambed material:

Discharge Data (cfs):

$$
\mathrm{Q}_{2.33}-
$$

Record flood date ( $M M / D D / Y Y)$ :

Estimated Discharge (cfs): Ice conditions (Heavy, Moderate, Light) : -

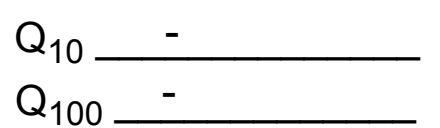

$$
\begin{aligned}
& Q_{25}- \\
& Q_{500}-
\end{aligned}
$$

Water surface elevation $(f t):-$ $(\mathrm{ft} / \mathrm{s}):$

The stage increases to maximum highwater elevation (Rapidly, Not rapidly):

The stream response is (Flashy, Not flashy):

Describe any significant site conditions upstream or downstream that may influence the stream's stage: This bridge may be eliminated under a proposal to straighten the channel and build a slightly larger bridge where the current bridge no. 16 is located just downstream. The proposal is currently being considered by the Corp. of engineers, who will permit the project and channel straightening if approved.

Watershed storage area (in percent):

The watershed storage area is: - (1-mainly at the headwaters; 2- uniformly distributed; 3-immediatly upstream oi the site)

Water Surface Elevation Estimates for Existing Structure:

\begin{tabular}{|l|l|l|l|l|l|}
\hline Peak discharge frequency & $Q_{2.33}$ & $Q_{10}$ & $Q_{25}$ & $Q_{50}$ & $Q_{100}$ \\
Water surface elevation (ft)) & - & - & - & - & - \\
Velocity (ft/sec) & - & - & - & - & - \\
\hline
\end{tabular}

Long term stream bed changes: -

Is the roadway overtopped below the $\mathrm{Q}_{100}$ ? (Yes, No, Unknown): $\mathbf{U}$ Frequency: Relief Elevation $(f t)$ :

Discharge over roadway at $Q_{100}\left(f^{3} / \mathrm{sec}\right)$ :

Are there other structures nearby? (Yes, No, Unknown): $\mathbf{Y}$ Upstream distance (miles): $\mathbf{0 . 2}$ Town: If No or Unknown, type ctrl-n os Highway No. : TH07 Structure No. : 18 Year Built: 1929

Clear span $(f t): \underline{\mathbf{2 0 . 2}}$ Clear Height $(f t): \mathbf{8 . 0}$ Full Waterway $\left(t^{2}\right):$ 
Downstream distance (miles): $\underline{\mathbf{0 . 3}}$ Town: Burke

Highway No. : TH07 Structure No. : 16 Year Built:

Clear span (ft): $\underline{\mathbf{2 4 . 8}}$ Clear Height $(f t): \underline{7.5}$ Full Waterway $\left(f^{2}\right): \underline{\mathbf{1 8 6 . 0}}$

Comments:

has a full-height vertical crack through the wall and its footing. A 6 foot section at the downstream end is reported undermined between 4 and 12 inches vertically with horizontal penetration reaching between 6 and 30 inches. Both abutment walls have a few minor cracks and spalls overall. The report mentions a few boulders present on bank areas where previous erosion has occurred both up- and downstream from the bridge. The foundation type recorded for this bridge site is an unknown foundation. A full hydraulics report does not exist in the files.

\section{USGS Watershed Data}

Watershed Hydrographic Data

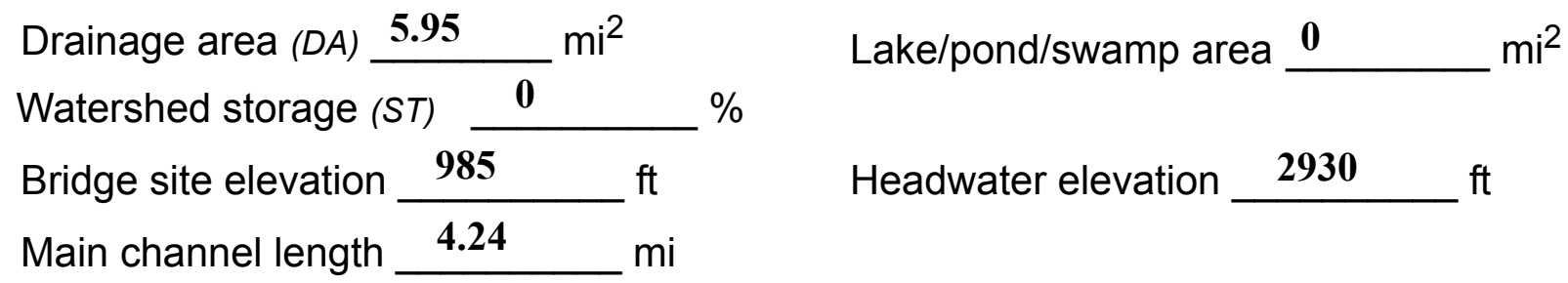

$10 \%$ channel length elevation $\quad \mathbf{1 0 7 0} \quad \mathrm{ft} \quad 85 \%$ channel length elevation $\underline{\mathbf{2 0 3 0}} \mathrm{ft}$ Main channel slope $(S) \quad \mathbf{2 6 9 . 3 1} \mathrm{ft} / \mathrm{mi}$

Watershed Precipitation Data

Average site precipitation in Average headwater precipitation in

Maximum 2yr-24hr precipitation event $(124,2)$ in

Average seasonal snowfall (Sn) $\mathrm{ft}$ 


\section{Bridge Plan Data}

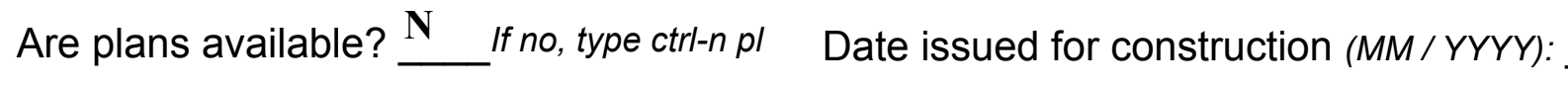

Project Number

Minimum channel bed elevation:

Low superstructure elevation: USLAB DSLAB USRAB DSRAB Benchmark location description:

NO BENCHMARK INFORMATION

Reference Point (MSL, Arbitrary, Other): Datum (NAD27, NAD83, Other):

Foundation Type: 4

If 1 : Footing Thickness

If 2: Pile Type:

If 3: Footing bottom elevation:

Is boring information available? $\mathbf{N}$

Foundation Material Type: $\mathbf{3}$

(1-Spreadfooting; 2-Pile; 3- Gravity; 4-Unknown)

Footing bottom elevation: -

Briefly describe material at foundation bottom elevation or around piles:

NO FOUNDATION MATERIAL INFORMATION

Comments:

NO PLANS. 


\section{Cross-sectional Data}

Is cross-sectional data available? $\underline{\mathbf{Y}}$

If no, type ctrl-n xs

Source (FEMA, VTAOT, Other)? VTAOT

Comments: This cross section is the downstream face. The low chord elevations are from the survey log done for this report on $8 / 7 / 95$. The low chord to bed length data is from the sketch attached to a bridge inspection report dated 10/31/94. The sketch was done on 10/27/92.

\begin{tabular}{|c|c|c|c|c|c|c|c|c|c|c|c|}
\hline Station & 0 & 3.2 & 17.3 & 21 & - & - & - & - & - & - & - \\
\hline Feature & RAB & & & LAB & - & - & - & - & - & - & - \\
\hline $\begin{array}{l}\text { Low chord } \\
\text { elevation }\end{array}$ & 498.4 & 498.4 & 498.5 & 498.5 & - & - & - & - & - & - & - \\
\hline $\begin{array}{l}\text { Bed } \\
\text { elevation }\end{array}$ & 493.3 & 492.1 & 490.5 & 493.7 & - & - & - & - & - & - & - \\
\hline $\begin{array}{l}\text { Low chord- } \\
\text { bed }\end{array}$ & 5.1 & 6.3 & 8.0 & 4.8 & - & - & - & - & - & - & - \\
\hline Station & - & - & - & - & - & - & - & - & - & - & - \\
\hline Feature & - & - & - & - & - & - & - & - & - & - & - \\
\hline $\begin{array}{l}\text { Low chord } \\
\text { elevation }\end{array}$ & - & - & - & - & - & - & - & - & - & - & - \\
\hline $\begin{array}{l}\text { Bed } \\
\text { elevation }\end{array}$ & - & - & - & - & - & - & - & - & - & - & - \\
\hline $\begin{array}{l}\text { Low chord- } \\
\text { bed }\end{array}$ & - & - & - & - & - & - & - & - & - & - & - \\
\hline
\end{tabular}

Source (FEMA, VTAOT, Other)?

Comments: -

\begin{tabular}{|c|c|c|c|c|c|c|c|c|c|c|c|}
\hline Station & - & - & - & - & - & - & - & - & - & - & - \\
\hline Feature & - & - & - & - & - & - & - & - & - & - & - \\
\hline $\begin{array}{l}\text { Low chord } \\
\text { elevation }\end{array}$ & - & - & - & - & - & - & - & - & - & - & - \\
\hline $\begin{array}{l}\text { Bed } \\
\text { elevation }\end{array}$ & - & - & - & - & - & - & - & - & - & - & - \\
\hline $\begin{array}{l}\text { Low chord- } \\
\text { bed }\end{array}$ & - & - & - & - & - & - & - & - & - & - & - \\
\hline Station & - & - & - & - & - & - & - & - & - & - & - \\
\hline Feature & - & - & - & - & - & - & - & - & - & - & - \\
\hline $\begin{array}{l}\text { Low chord } \\
\text { elevation }\end{array}$ & - & - & - & - & - & - & - & - & - & - & - \\
\hline $\begin{array}{l}\text { Bed } \\
\text { elevation }\end{array}$ & - & - & - & - & - & - & - & - & - & - & - \\
\hline $\begin{array}{l}\text { Low chord- } \\
\text { bed }\end{array}$ & - & - & - & - & - & - & - & - & - & - & - \\
\hline
\end{tabular}




\section{APPENDIX E: \\ LEVEL I DATA FORM}


U. S. Geological Survey

Bridge Field Data Collection and Processing Form

Qa/Qc Check by: $\mathbf{R B}$ Date: $2 / 29 / 96$

\section{Structure Number}

BURKTH00070017

Computerized by: $\underline{\mathbf{R B}}$ Date: $2 / 29 / 96$

Reviewd by: $\quad$ RB Date: $\underline{\mathbf{8} / \mathbf{2 2} / 97}$

\section{A. General Location Descriptive}

1. Data collected by (First Initial, Full last name) E. BOEHMLER

Date $(M M / D D / Y Y)$

7

2. Highway District Number 07

County CALEDONIA 005

Waterway (I - 6) DISH MILL BROOK

Route Number $\mathbf{T H 0 7}$

3. Descriptive comments:

Located about 0.6 miles east of the intersection of TH07 with VT114.
Mile marker 0000

Town BURKE 10450

Road Name -

Hydrologic Unit Code: $\mathbf{0 1 0 8 0 1 0 2}$

\section{B. Bridge Deck Observations}
4. Surface cover... LBUS 6
RBUS 6
LBDS 5
RBDS 6
Overall 6

(2b us,ds,lb,rb: 1- Urban; 2- Suburban; 3- Row crops; 4- Pasture; 5- Shrub- and brushland; 6- Forest; 7- Wetland)
5. Ambient water surface... US 2
UB 2
DS 2
(1- pool; 2- riffle)

6. Bridge structure type 1 (1- single span; 2- multiple span; 3- single arch; 4- multiple arch; 5-cylindrical culvert; 6- box culvert; or 7- other)
7. Bridge length 26
(feet)
Span length $\mathbf{2 3}$
(feet)
Bridge width 23.2 (feet)

\section{Road approach to bridge:}
8. LB 1
RB 2
( 0 even, 1- lower, 2- higher)
9. LB RB 1
(1-Paved, 2- Not paved)

10. Embankment slope (run / rise in feet / foot)

US left

US right

\begin{tabular}{|c|c|c|c|}
\hline \multicolumn{2}{|c|}{ Protection } & \multirow{2}{*}{ 13.Erosion } & 14.Severity \\
\hline 11.Type & 12.Cond. & $\mathbf{0}$ & $\mathbf{0}$ \\
\hline $\mathbf{0}$ & - & $\mathbf{0}$ & $\mathbf{1}$ \\
\hline $\mathbf{2}$ & $\mathbf{1}$ & $\mathbf{2}$ & $\mathbf{1}$ \\
\hline $\mathbf{0}$ & - & $\mathbf{2}$ & $\mathbf{1}$ \\
\hline $\mathbf{0}$ & - & $\mathbf{0}$ & $\mathbf{0}$ \\
\hline
\end{tabular}

Bank protection types: 0- none; 1- < 12 inches;

2- < 36 inches; 3- < 48 inches;

4- < 60 inches; 5- wall / artificial levee

Bank protection conditions: 1- good; 2- slumped;

3- eroded; 4- failed

Erosion: 0 - none; 1- channel erosion; 2 -

road wash; 3- both; 4- other

Erosion Severity: 0 - none; 1- slight; 2- moderate; 3- severe

\section{Channel approach to bridge (BF):}

15. Angle of approach: 0

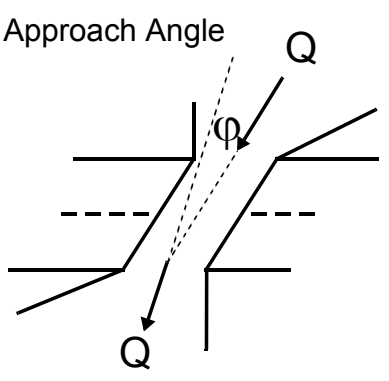

17. Channel impact zone 1:

Where? LB $(L B, R B)$

Range? 115 feet $\underline{\text { US }}$

Channel impact zone 2:

Where? LB $(L B, R B)$

Range? 10 feet $\underline{\mathbf{U S}}$

Impact Severity: 0- none to very slight; 1- Slight; 2- Moderate; 3- Severe
16. Bridge skew: 10 Bridge Skew Angle

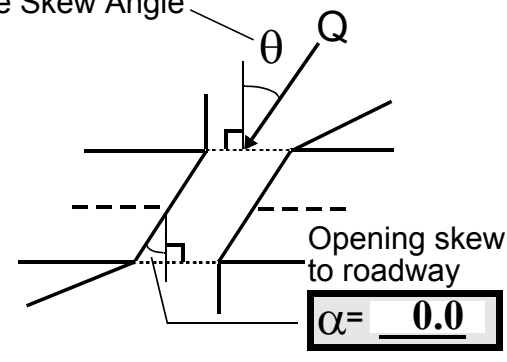

\section{Exist? $\mathbf{Y}(\mathrm{Y}$ or $N)$}

Severity 2

(US, UB, DS) to $\mathbf{9 0}$ feet $\underline{\mathbf{U S}}$

Exist? $\mathbf{Y}(Y$ or $N)$

Severity 1

$U B, D S)$ to $\underline{\mathbf{0}}$ feet $\underline{\mathbf{D S}}$ 
18. Bridge Type: 1a

1a- Vertical abutments with wingwalls

1 b- Vertical abutments without wingwalls

2- Vertical abutments and wingwalls, sloping embankment Wingwalls parallel to abut. face

3- Spill through abutments

4- Sloping embankment, vertical wingwalls and abutments

Wingwall angle less than $90^{\circ}$.

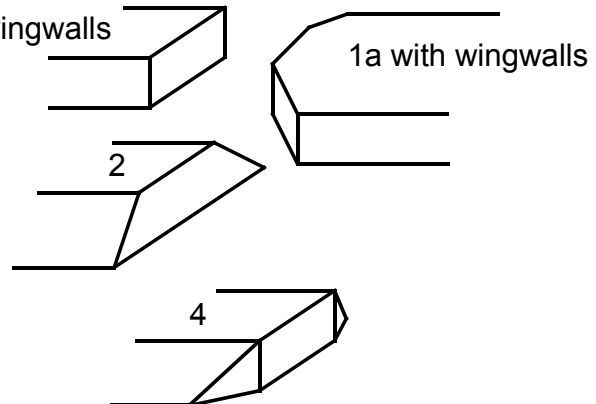

19. Bridge Deck Comments (surface cover variations, measured bridge and span lengths, bridge type variations, approach overflow width, etc.)

7. Values from the VT AOT files. Measured values of the bridge length $=\mathbf{2 6 . 5}$ feet, span length $=\mathbf{2 3 . 5}$ feet, and bridge width $=\mathbf{2 3 . 3}$ feet.

4. The surface cover is as indicated except on the DS left bank where shrubs and brush make up $80 \%$ of the area with the remaining being tree coverage along the immediate bank.

13. Roadwash on the DS right and left banks is very slight. While there is a road drainage ditch that enters just DS on the right bank, the ditch is well away from the DS right wingwall. There is also a small drainage pipe that takes off roadway water that enters here. The US right wingwall has a history of roadwash erosion according to the historical form. There is fill material in place on the bank just US of the US right wingwall and paving on the road embankment behind the wingwall. There are also many storm drainage gullies in the road embankment material which drain into a larger ditch running parallel with the road embankment to the right bank of the stream. Currently there is only slight erosion here.

\section{Upstream Channel Assessment}

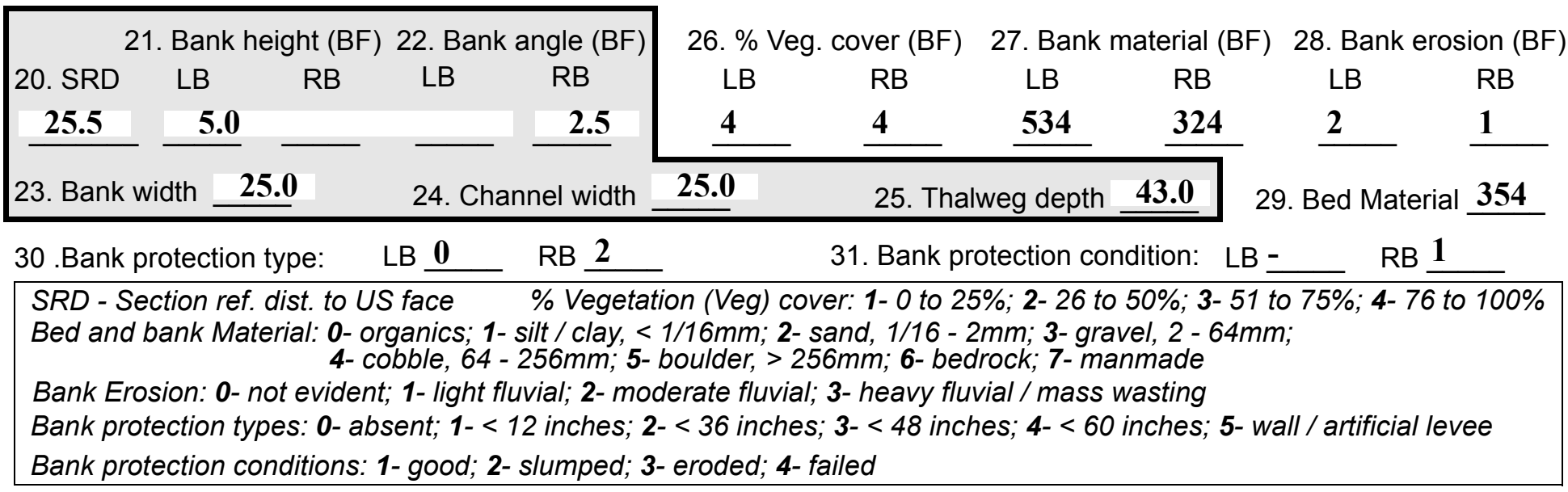

32. Comments (bank material variation, minor inflows, protection extent, etc.):

The protection on the right bank is in the range of 20 feet US to 10 feet US where the same stone fill begins protecting the US right wingwall. 
33.Point/Side bar present? $\mathbf{N}(Y$ or $N$. if $N$ type ctrl-n pb)34. Mid-bar distance: -

35. Mid-bar width: -

36. Point bar extent: feet (US, UB) to feet (US, UB, DS) positioned $\%$ LB to $\%$ RB

37. Material: -

38. Point or side bar comments (Circle Point or Side; Note additional bars, material variation, status, etc.):

NO POINT BARS

39. Is a cut-bank present? $\mathbf{Y}$ (Y or if $N$ type ctrl-n cb)

40. Where? $\underline{\mathbf{L B}}$ (LB or RB)

41. Mid-bank distance: $\mathbf{1 0 0}$

42. Cut bank extent: 135 feet $\mathbf{U S}$ (US, UB) to 0 feet $\underline{\mathbf{U S}}$ (US, UB, DS)

43. Bank damage: $\mathbf{3}$

(1- eroded and/or creep; 2- slip failure; 3- block failure)

44. Cut bank comments (eg. additional cut banks, protection condition, etc.):

Whole trees have fallen over with the trunk still in the failed bank material. The bank appears undermined as erosion is concentrated where the soil is in contact with the semi-alluvial bouldery, cobbley, gravel material underneath. There is extensive exposure of tree roots in the eroding soil layer along the entire extent of the left bank US indicated above.

45. Is channel scour present? $\mathbf{N}$ ( $Y$ or if $N$ type ctrl-n cs) 46. Mid-scour distance: -

47. Scour dimensions: Length Width Depth : -

Position $\%$ LB to $\% \mathrm{RB}$

48. Scour comments (eg. additional scour areas, local scouring process, etc.):

NO CHANNEL SCOUR

49. Are there major confluences? $\mathbf{Y}$ ( $Y$ or if $N$ type ctrl-n $m c)$

51. Confluence 1: Distance 35

Confluence 2: Distance -
52. Enters on $\underline{\mathbf{R B}}$ ( $L B$ or $R B)$

Enters on (LB or $R B)$

54. Confluence comments (eg. confluence name):

The confluence is nameless, but at the mouth has a $15 \mathrm{ft}$ width and forms a cut off channel taking flow during over bank floods, which occurred on about August 4, 1995.

\section{Under Bridge Channel Assessment}

55. Channel restraint (BF)? LB 2

\begin{tabular}{|ccccc}
\hline \multicolumn{2}{|c}{ 56. Height (BF) } & \multicolumn{2}{c}{57 Angle (BF) } \\
LB & RB & LB & RB \\
$\mathbf{2 9 . 0}$ & & & $\mathbf{1 . 5}$ & \\
\hline
\end{tabular}
(1- natural bank; 2- abutment; 3- artificial levee)

58. Bank width (BF) -

59. Channel width -

61. Material (BF)

LB RB

$2 \quad 7$
62. Erosion (BF)

LB RB

7
50. How many? 1

53. Type 2 (1-perennial; 2- ephemeral)

Type (1-perennial; 2-ephemeral)

Bed and bank Material: 0- organics; 1- silt / clay, < 1/16mm; 2- sand, 1/16 - 2mm; 3- gravel, 2 - 64mm; 4- cobble, 64 - 256mm; 5- boulder, > 256mm; 6- bedrock; 7- manmade

Bank Erosion: 0- not evident; 1- light fluvial; 2- moderate fluvial; 3- heavy fluvial / mass wasting

64. Comments (bank material variation, minor inflows, protection extent, etc.):

345

The thalweg mainly runs along the left abutment and the bed elevation is about 1 foot lower along the left abutment side than along the right abutment side. Bed erosion also seems concentrated along the left abutment footing. 
65. Debris and Ice Is there debris accumulation?

67. Debris Potential (1- Low; 2- Moderate; 3- High)

69. Is there evidence of ice build-up? $\underline{1}(Y$ or $N)$

70. Debris and Ice Comments:

1

The stream has a lot of cut banks with lots of trees on the banks lending to a high potential for debris generation but the reach through the bridge is straight and at a high gradient, with few obstructions. For these reasons, debris and ice probably do not accumulate at this site.

\begin{tabular}{|l|c|c|c|c|c|c|c|c|}
\hline Abutments & $\begin{array}{c}\text { 71. Attack } \\
\angle \text { (BF) }\end{array}$ & $\begin{array}{c}\text { 72. Slope } \angle \\
\text { (Qmax) }\end{array}$ & $\begin{array}{c}\text { 73. Toe } \\
\text { loc. (BF) }\end{array}$ & $\begin{array}{c}\text { 74. Scour } \\
\text { Condition }\end{array}$ & $\begin{array}{c}75 . \text { Scour } \\
\text { depth }\end{array}$ & $\begin{array}{c}\text { 76. Exposure } \\
\text { depth }\end{array}$ & 77. Material & 78. Length \\
\hline LABUT & & $\mathbf{1 0}$ & $\mathbf{9 0}$ & $\mathbf{2}$ & $\mathbf{3}$ & $\mathbf{1 . 5}$ & $\mathbf{4 . 0}$ & $\mathbf{9 0 . 0}$ \\
\hline RABUT & $\mathbf{1}$ & - & $\mathbf{9 0}$ & & & $\mathbf{2}$ & $\mathbf{2}$ & $\mathbf{2 2 . 5}$ \\
\hline
\end{tabular}

Pushed: $L B$ or RB

Toe Location (Loc.): 0- even, 1- set back, 2- protrudes

Scour cond.: 0- not evident; 1- evident (comment); 2- footing exposed; 3-undermined footing; 4- piling exposed; 5- settled; 6- failed

Materials: 1- Concrete; 2- Stone masonry or drywall; 3- steel or metal; 4- wood

79. Abutment comments (eg. undermined penetration, unusual scour processes, debris, etc.):

0

1.5

1

The right abutment footing is exposed but not undermined. The exposure varies randomly from 1.0-1.5 feet. The undermined portion of the left abutment is only along the DS end for 8 feet. The footing and subfooting have settled a bit here as there is a vertical crack up through both footings and the height of the left abutment wall about 8 feet under the bridge from the DS face. The remaining portion of the footing/subfooting is only exposed between 1.5 and 2.5 feet. There is a scour hole along the DS end of the left abutment and the DS left wingwall which is 24 feet long, from $7 \mathrm{ft}$ under the bridge to $17 \mathrm{ft}$ DS. It is 8 feet wide and 1.5 feet deep at the deepest point located about 1 foot DS of the DS face and positioned $0 \%$ LB - 0\% RB.

80. Wingwalls:

$$
\begin{aligned}
& \text { Exist? Material? Scour Scour Exposure } \begin{array}{l}
81 . \\
\text { Angle? Length? }
\end{array} \\
& \text { Condition? depth? depth? }
\end{aligned}
$$

USLWW:

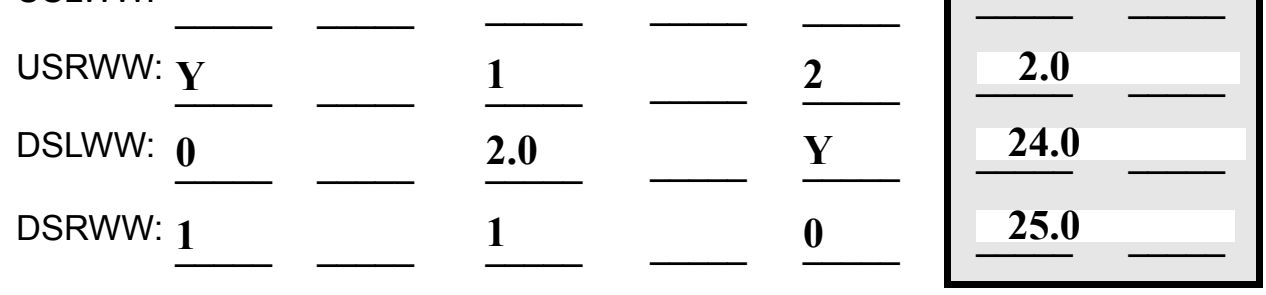

Wingwall materials: 1- Concrete; 2- Stone masonry or drywall; 3- steel or metal; 4- wood

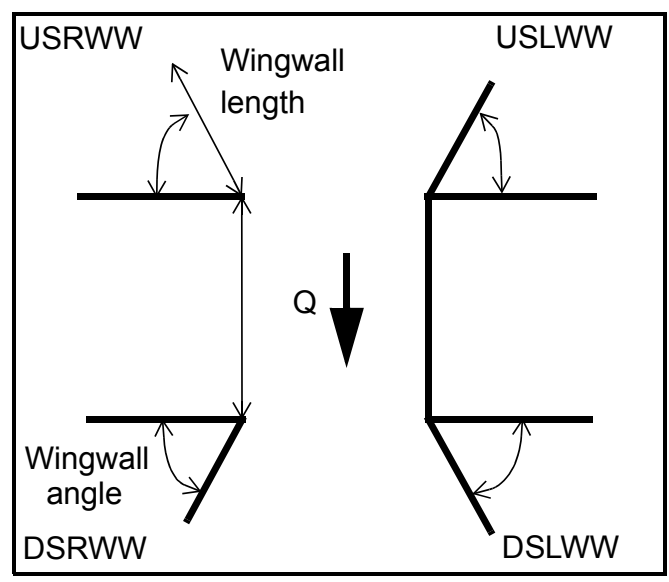

82. Bank / Bridge Protection:

\begin{tabular}{|l|l|l|l|l|l|l|l|l|}
\hline Location & USLWW & USRWW & LABUT & RABUT & LB & RB & DSLWW & DSRWW \\
\hline Type & $\mathbf{1 . 0}$ & $\mathbf{3}$ & $\mathbf{Y}$ & $\mathbf{0}$ & - & $\mathbf{1}$ & - & - \\
\hline Condition & $\mathbf{Y}$ & $\mathbf{1 . 0}$ & $\mathbf{1}$ & $\mathbf{0 . 5}$ & - & $\mathbf{1}$ & - & - \\
\hline Extent & $\mathbf{1}$ & $\mathbf{3 . 0}$ & $\mathbf{2}$ & $\mathbf{0}$ & $\mathbf{2}$ & $\mathbf{0}$ & $\mathbf{0}$ & - \\
\hline
\end{tabular}

Bank / Bridge protection types: 0- absent; 1- < 12 inches; 2- < 36 inches; 3- < 48 inches; 4- < 60 inches; 
83. Wingwall and protection comments (eg. undermined penetration, unusual scour processes, etc.):

-
-
-
-
-
3
1
3
1
2
3

\section{Piers:}

84. Are there piers? Th (Y or if N type ctrl-n pr)

\begin{tabular}{|l|l|r|r|l|l|l|l|}
\hline \multirow{2}{*}{$\begin{array}{l}85 . \\
\text { Pier no. }\end{array}$} & \multicolumn{3}{|c|}{ width (w) feet } & \multicolumn{5}{c|}{ elevation (e) feet } \\
\cline { 2 - 8 } & w1 & w2 & w3 & e@w1 & e@w2 & e@w3 \\
\hline Pier 1 & & $\mathbf{9 . 0}$ & & $\mathbf{5 5 . 0}$ & $\mathbf{3 0 . 0}$ & $\mathbf{1 1 . 0}$ \\
\hline Pier 2 & & $\mathbf{9 . 0}$ & $\mathbf{6 . 5}$ & $\mathbf{4 5 . 0}$ & $\mathbf{2 0 . 0}$ & - & - \\
\hline Pier 3 & - & - & - & - & - & - \\
\hline Pier 4 & - & - & - & - & - & - \\
-
\end{tabular}

\begin{tabular}{|l|l|l|l|l|}
\hline Level 1 Pier Descr. & \multicolumn{1}{|c|}{1} & \multicolumn{1}{|c|}{2} & \multicolumn{1}{|c|}{3} & \multicolumn{1}{|c|}{4} \\
\hline 86. Location (BF) & e foot- & with & right & right \\
\hline 87. Type & ing & type- & wing & abut \\
\hline 88. Material & on & 2 & wall & ment \\
\hline 89. Shape & the & stone & foot- & foot- \\
\hline 90. Inclined? & US & fill & ing is & ing \\
\hline 91. Attack $\angle$ (BF) & right & its & expo & abou \\
\hline 92. Pushed & wing & entir & sed & t 0.5 \\
\hline 93. Length (feet) & - & - & - & - \\
\hline 94. \# of piles & wall & e & near & feet, \\
\hline 95. Cross-members & has & lengt & wher & then \\
\hline 96. Scour Condition & been & h. & e it & the \\
\hline 97. Scour depth & cov- & The & meet & foot- \\
\hline 98. Exposure depth & ered & DS & s the & ing is \\
\hline
\end{tabular}

LFP, LTB, LB, MCL, MCM, MCR, RB, RTB, RFP

1- Solid pier, 2- column, 3- bent

1-Wood; 2- concrete; 3- metal; 4- stone

1- Round; 2- Square; 3- Pointed

Y-yes; $N$ - no

$L B$ or $R B$

0- none; 1- laterals; 2- diagonals; 3- both

0- not evident; 1- evident (comment);

2- footing exposed; 3- piling exposed;

4- undermined footing; 5- settled; 6- failed 
99. Pier comments (eg. undermined penetration, protection and protection extent, unusual scour processes, etc.):

covered by road embankment fill material, which is slumping as material is eroded along the toe of the fill. The DS left wingwall footing and subfooting are undermined with up to 2 feet of penetration. Protection here is type-3 and includes a very large boulder around and over which the DS left wingwall footing is molded.

100.

\section{E. Downstream Channel Assessment}

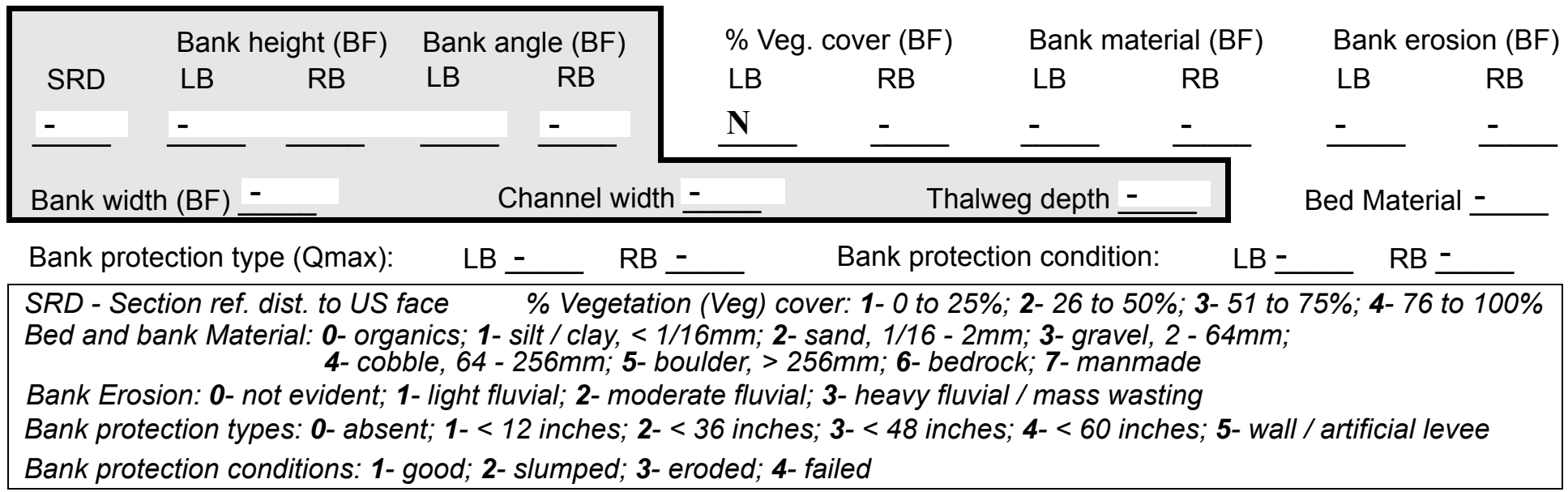

Comments (eg. bank material variation, minor inflows, protection extent, etc.):

$-$

$-$

-

-

-

-

-

-

$-$

$-$

\section{Is a drop structure present? __ ( $Y$ or $N$, if $N$ type ctrl-n $d s) \quad$ 102. Distance: ___ feet}
103. Drop: - feet
104. Structure material: -
(1- steel sheet pile; 2- wood pile; 3- concrete; 4- other)

105. Drop structure comments (eg. downstream scour depth): 
106. Point/Side bar present? (Y or $N$. if $N$ type ctrl-n pb)Mid-bar distance: Mid-bar width: -

Point bar extent: feet (US, UB, DS) to feet (US, UB, DS) positioned $\%$ LB to $\%$ RB Material:

Point or side bar comments (Circle Point or Side; note additional bars, material variation, status, etc.):

-

Is a cut-bank present? - ( $Y$ or if $N$ type ctrl-n $c b)$ Where? NO (LB or RB) Mid-bank distance: PIE Cut bank extent: RS feet__ (US, UB, DS) to feet (US, UB, DS)

Bank damage: (1- eroded and/or creep; 2- slip failure; 3- block failure)

Cut bank comments (eg. additional cut banks, protection condition, etc.):

Is channel scour present? ( $Y$ or if $N$ type ctrl-n cs) Width 235 Depth: 523 Scour dimensions: Length 4

Scour comments (eg. additional scour areas, local scouring process, etc.): 345

0

$\mathbf{0}$

Are there major confluences? Confluence 1: Distance Enters on ( $(L B$ or $R B)$

Mid-scour distance: $\underline{4}$

Confluence 2: Distance

Enters on ( $L B$ or $R B)$

Positioned 2 \%LB to 2 $\% \mathrm{RB}$

Confluence comments (eg. confluence name):

\section{F. Geomorphic Channel Assessment}

107. Stage of reach evolution

1- Constructed

2- Stable

3- Aggraded

4- Degraded

5- Laterally unstable

6- Vertically and laterally unstable 
108. Evolution comments (Channel evolution not considering bridge effects; See HEC-20, Figure 1 for geomorphic descriptors):

$\mathbf{N}$

$-$

NO DROP STRUCTURE 


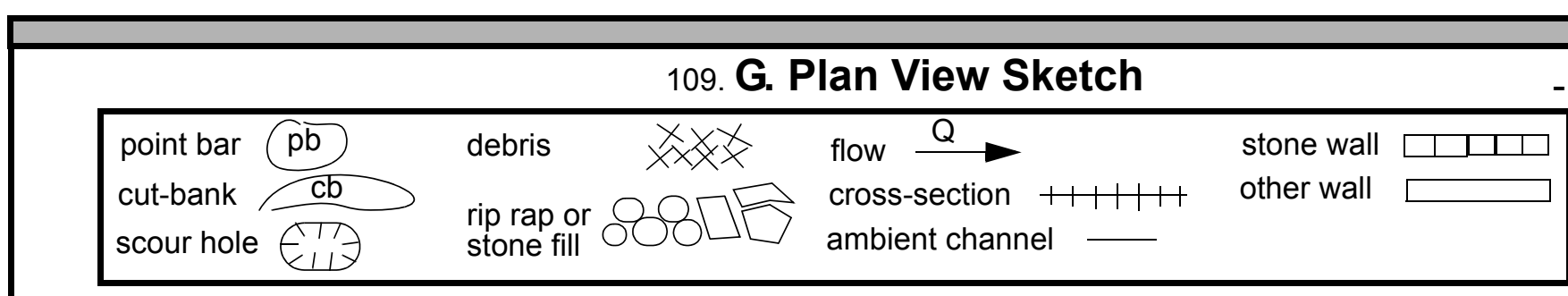


APPENDIX F:

SCOUR COMPUTATIONS 


\begin{tabular}{|c|c|c|c|}
\hline Structure Number: BURKTH00070017 & & Town: & BURKE \\
\hline Road Number: & & County: & CALEDONIA \\
\hline Stream: DISH MILL BROOK & & & \\
\hline Initials RLB & Checked: & $\mathrm{ECW}$ & \\
\hline nalysis of contraction scour, liv & bed or $\mathrm{C}$ & lear wate & \\
\hline $\begin{array}{l}\text { Critical Velocity of Bed Material } \\
\mathrm{VC}=11.21^{*} \mathrm{y}^{\wedge} 0.1667 * \mathrm{D} 50^{\wedge} 0.33 \text { with } \\
\text { (Richardson and others, } 1995, \mathrm{p} .\end{array}$ & $\begin{array}{l}\text { converted } \\
=2.65 \\
\text { eq. } 16)\end{array}$ & to Engl: & sh units) \\
\hline pproach section & & & \\
\hline Characteristic & $100 \mathrm{yr}$ & $500 \mathrm{yr}$ & other $\mathrm{Q}$ \\
\hline Total discharge, cfs & 1400 & 1890 & 1350 \\
\hline Main Channel Area, ft2 & 300 & 324 & 293 \\
\hline Left overbank area, ft2 & 67 & 89 & 60 \\
\hline Right overbank area, ft2 & 76 & 95 & 71 \\
\hline Top width main channel, ft & 44 & 44 & 44 \\
\hline Top width L overbank, ft & 43 & 43 & 42 \\
\hline Top width $\mathrm{R}$ overbank, ft & 33 & 39 & 32 \\
\hline D50 of channel, ft & 0.2414 & 0.2414 & 0.2414 \\
\hline D50 left overbank, ft & -- & -- & -- \\
\hline D50 right overbank, ft & -- & -- & -- \\
\hline Y1, average depth, MC, ft & 6.8 & 7.4 & 6.7 \\
\hline y1, average depth, LOB, ft & 1.6 & 2.1 & 1.4 \\
\hline Y1, average depth, ROB, ft & 2.3 & 2.4 & 2.2 \\
\hline Total conveyance, approach & 32642 & 38395 & 31026 \\
\hline Conveyance, main channel & 27967 & 31689 & 26880 \\
\hline Conveyance, LOB & 1901 & 3057 & 1597 \\
\hline Conveyance, ROB & 2775 & 3649 & 2549 \\
\hline Percent discrepancy, conveyance & -0.0031 & 0.0000 & 0.0000 \\
\hline Qm, discharge, MC, cfs & 1199.5 & 1559.9 & 1169.6 \\
\hline Q1, discharge, LOB, Cfs & 81.5 & 150.5 & 69.5 \\
\hline Qr, discharge, ROB, cfs & 119.0 & 179.6 & 110.9 \\
\hline $\mathrm{Vm}$, mean velocity $\mathrm{MC}$, ft/s & 4.0 & 4.8 & 4.0 \\
\hline Vl, mean velocity, LOB, ft/s & 1.2 & 1.7 & 1.2 \\
\hline Vr, mean velocity, ROB, ft/s & 1.6 & 1.9 & 1.6 \\
\hline Vc-m, crit. velocity, MC, ft/s & 9.6 & 9.7 & 9.6 \\
\hline Vc-l, crit. velocity, LOB, ft/s & ERR & ERR & ERR \\
\hline Vc-r, crit. velocity, ROB, ft/s & $\mathrm{ERR}$ & ERR & ERR \\
\hline Results & & & \\
\hline Live-bed(1) or Clear-Water(0) Cont & action Sc & bur? & \\
\hline Main Channel & 0 & 0 & 0 \\
\hline Left Overbank & $\mathrm{N} / \mathrm{A}$ & $\mathrm{N} / \mathrm{A}$ & $\mathrm{N} / \mathrm{A}$ \\
\hline Right Overbank & $\mathrm{N} / \mathrm{A}$ & $\mathrm{N} / \mathrm{A}$ & $\mathrm{N} / \mathrm{A}$ \\
\hline
\end{tabular}


Clear Water Contraction Scour in MAIN CHANNEL

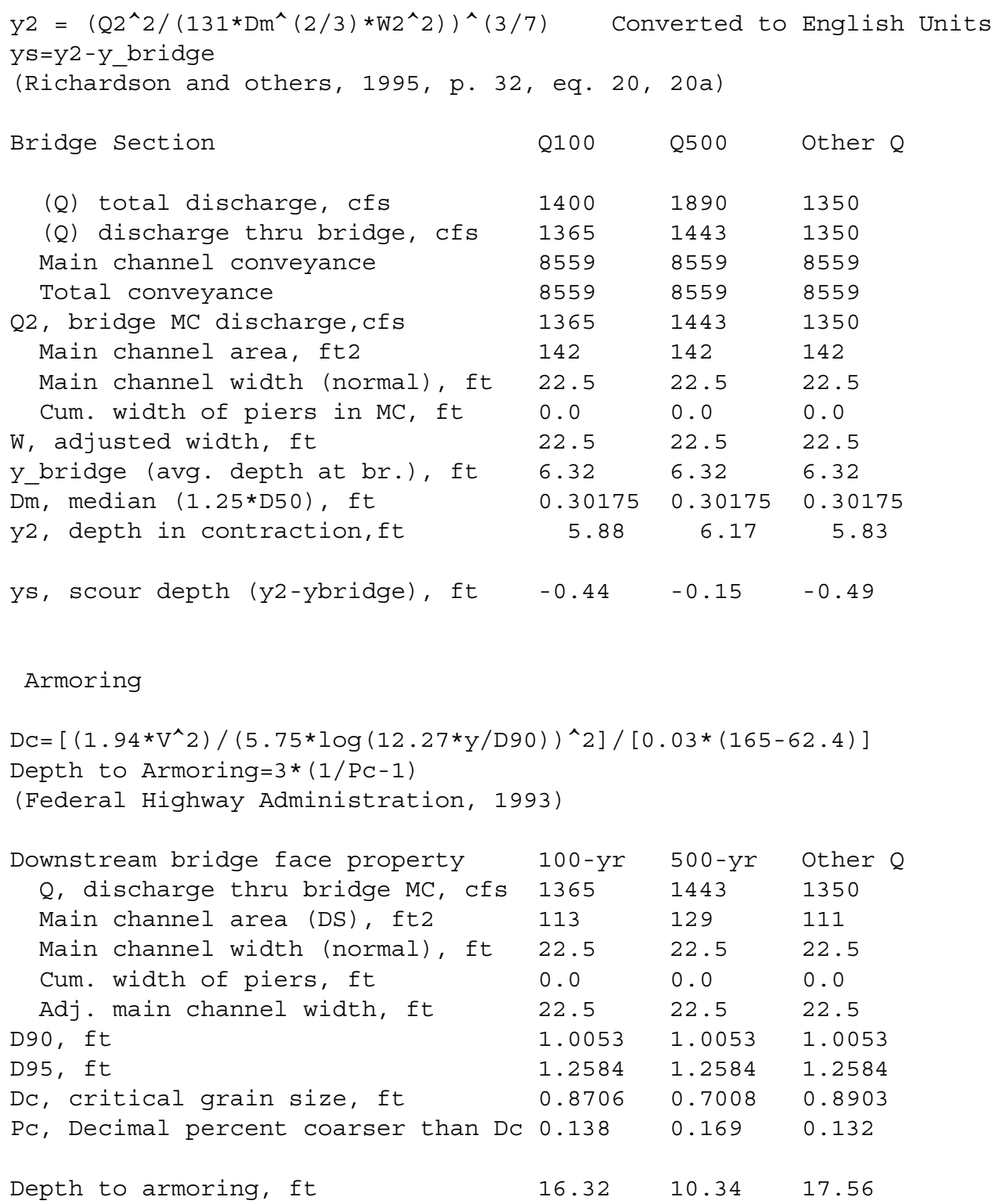




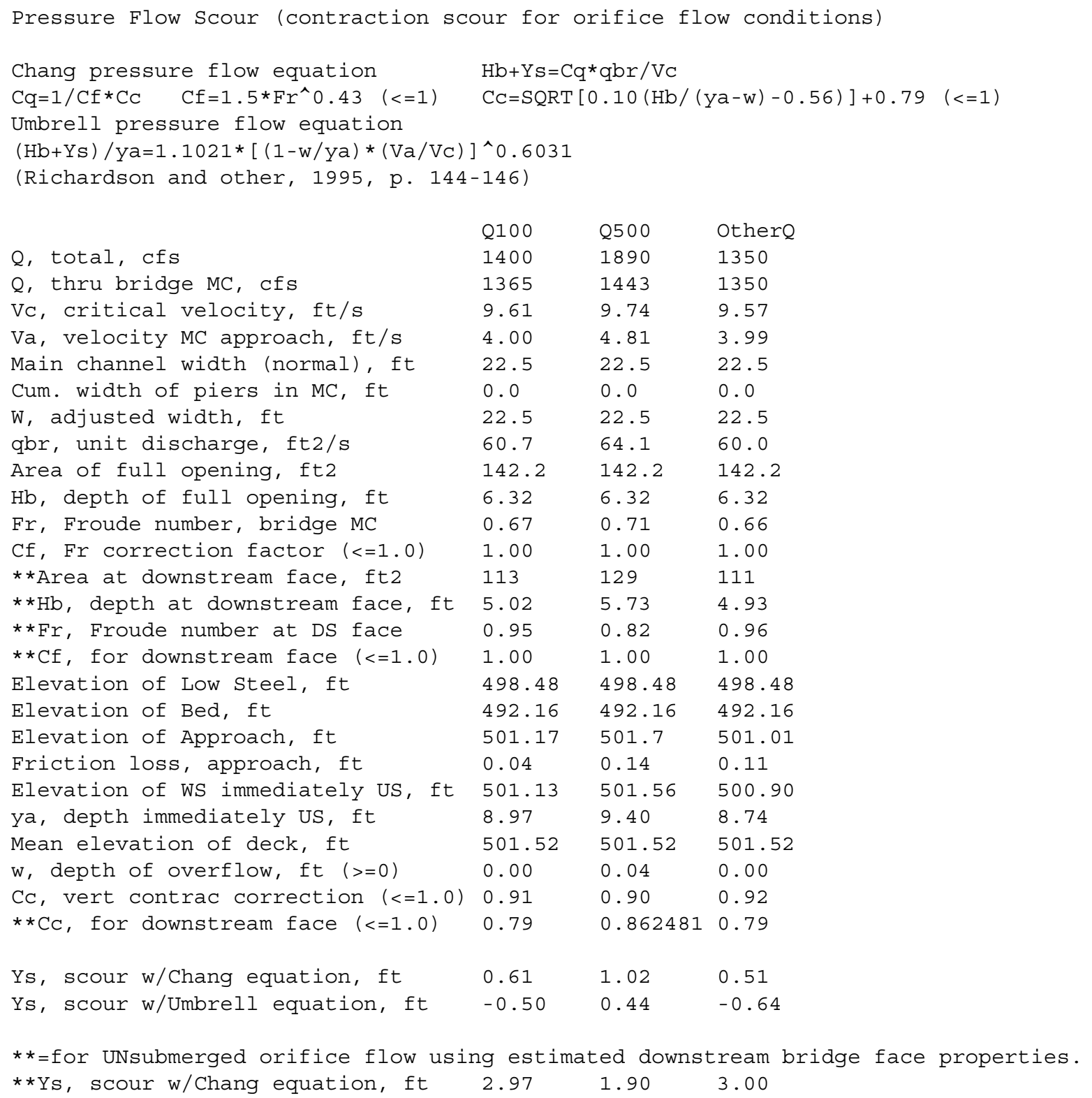


**Ys, scour w/Umbrell equation, ft $0.80 \quad 1.02 \quad 0.75$

In UNsubmerged orifice flow, an adjusted scour depth using the Laursen equation results and the estimated downstream bridge face properties can also be computed (ys=y2-ybridgeDs)

y2, from Laursen's equation, ft $5.88 \quad 6.17$

WSEL at downstream face, ft $\quad 497.17 \quad 497.91 \quad 497.08$

Depth at downstream face, ft $5.02 \quad 5.73 \quad 4.93$

Ys, depth of scour (Laursen), ft $0.86 \quad 0.44 \quad 0.89$

Abutment scour

Froehlich's Abutment Scour

$\mathrm{Ys} / \mathrm{Y} 1=2.27 * \mathrm{~K} 1 * \mathrm{~K} 2 *\left(\mathrm{a}^{\prime} / \mathrm{Y} 1\right)^{\wedge} 0.43 * \mathrm{Fr} 1^{\wedge} 0.61+1$

(Richardson and others, 1995, p. 48, eq. 28)

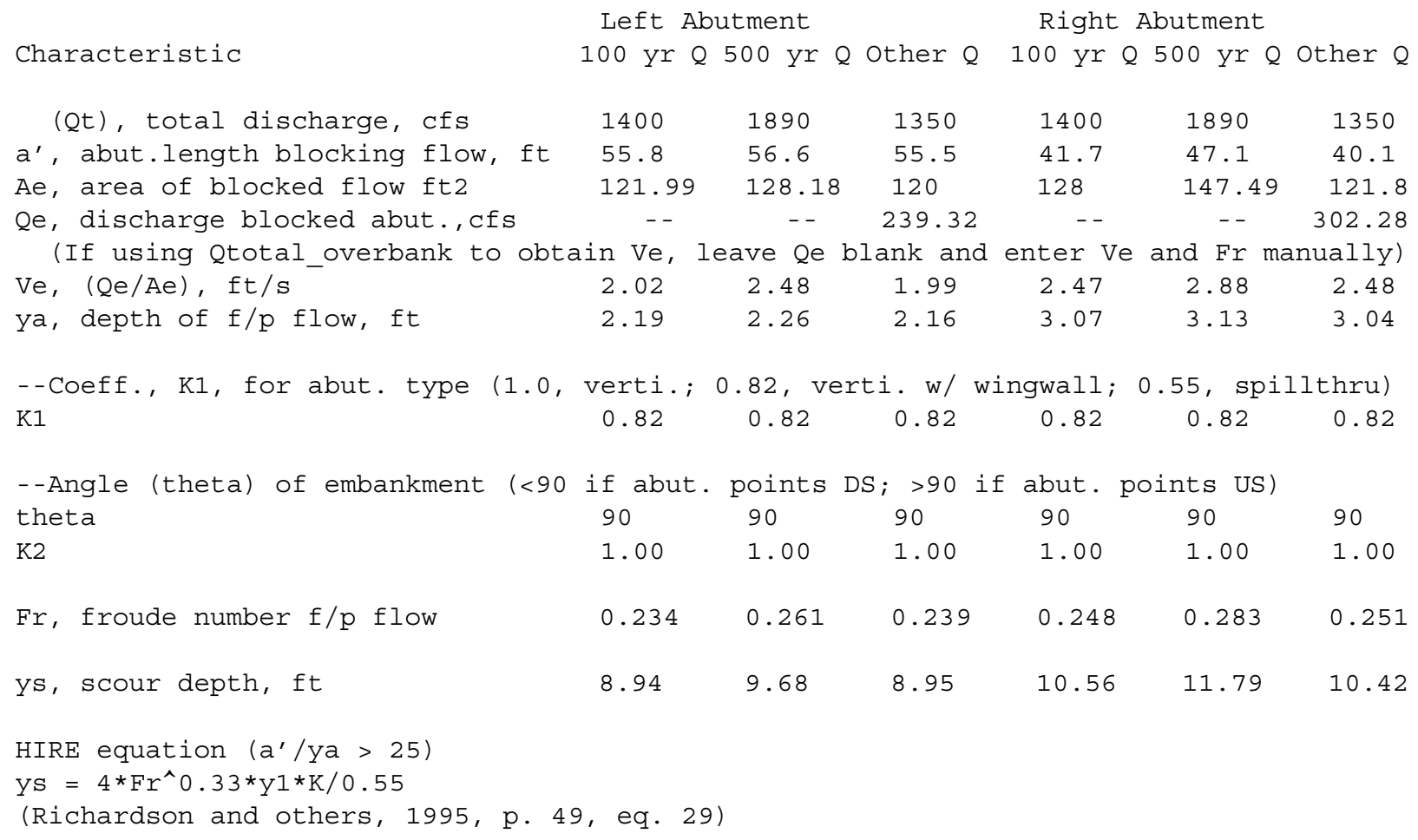




\begin{tabular}{|c|c|c|c|c|c|c|}
\hline$a^{\prime}$ (abut length blocked, ft) & 55.8 & 56.6 & 55.5 & 41.7 & 47.1 & 40.1 \\
\hline y1 (depth f/p flow, ft) & 2.19 & 2.26 & 2.16 & 3.07 & 3.13 & 3.04 \\
\hline$a^{\prime} / y^{\prime}$ & 25.52 & 25.00 & 25.67 & 13.59 & 15.04 & 13.20 \\
\hline Skew correction (p. 49, fig. 16) & 1.00 & 1.00 & 1.00 & 1.00 & 1.00 & 1.00 \\
\hline Froude no. f/p flow & 0.23 & 0.26 & 0.24 & 0.25 & 0.28 & 0.25 \\
\hline Ys w/ corr. factor $\mathrm{K} 1 / 0.55$ : & & & & & & \\
\hline vertical & 9.85 & 10.57 & 9.81 & $\mathrm{ERR}$ & ERR & ERR \\
\hline vertical w/ $w^{\prime}$ s & 8.07 & 8.67 & 8.04 & ERR & ERR & ERR \\
\hline spill-through & 5.41 & 5.82 & 5.39 & ERR & ERR & ERR \\
\hline \multicolumn{7}{|l|}{ Abutment riprap Sizing } \\
\hline \multirow{2}{*}{\multicolumn{7}{|c|}{$\begin{array}{l}\text { Isbash Relationship } \\
\mathrm{D} 50=\mathrm{Y}^{*} \mathrm{~K} * \mathrm{Fr} r^{\wedge} /(\mathrm{Ss}-1) \text { and } \mathrm{D} 50=\mathrm{Y}^{*} \mathrm{~K} *\left(\mathrm{Fr} r^{\wedge} 2\right)^{\wedge} 0.14 /(\mathrm{Ss}-1) \\
\text { (Richardson and others, 1995, p112, eq. 81,82) }\end{array}$}} \\
\hline & & & & & & \\
\hline Characteristic & Q100 & Q500 & Other $Q$ & Q100 & Q500 & Other $Q$ \\
\hline Fr, Froude Number & 0.95 & 0.82 & 0.96 & 0.95 & 0.82 & 0.96 \\
\hline$y$, depth of flow in bridge, ft & 5.02 & 5.73 & 4.93 & 5.02 & 5.73 & 4.93 \\
\hline Median Stone Diameter for riprap & left & utment & & right & abutment, & ft \\
\hline Fr $<=0.8$ (vertical abut.) & ERR & ERR & ERR & ERR & ERR & ERR \\
\hline Fr>0.8 (vertical abut.) & 2.07 & 2.27 & 2.04 & 2.07 & 2.27 & 2.04 \\
\hline
\end{tabular}

